\title{
ע ROYAL "CHARIOT" BURIALS OF SANAULI NEAR DELHI AND ARCHAEOLOGICAL CORRELATES OF PREHISTORIC INDO-IRANIAN LANGUAGES
}

\author{
Asko Parpola \\ University of Helsinki
}

\begin{abstract}
The article describes the royal cart burials excavated at the Late Harappan site of Sanauli near Delhi in the spring of 2018 on the basis of the available reports and photographs. The author then comments on these finds, dated to about 1900 BCE, with the Sanauli cart burials being the first of their kind in Bronze Age India. In his opinion, several indications suggest that the Sanauli "chariots" are actually carts yoked to bulls, as in the copper sculpture of a bull-cart from the Late Harappan site of Daimabad in Maharashtra. The antennae-hilted swords associated with the burials suggest that these bull-carts are likely to have come from the BMAC or the Bactria and Margiana Archaeological Complex (c.2300-1500 BCE) of southern Central Asia, from where there is iconographic evidence of bull-carts. The ultimate source of the Sanauli/BMAC bull-carts may be the early phase of the Sintashta culture in the Trans-Urals, where the chariot (defined as a horse-drawn light vehicle with two spoked wheels) was most probably invented around the late twenty-first century BCE. The invention presupposes an earlier experimental phase, which started with solid-wheeled carts that could only be pulled by bulls. An intermediate phase in the development is the "proto-chariot" with cross-bar wheels, attested in a BMAC-related cylinder seal from Tepe Hissar III B in northern Iran (c.2000-1900 BCE). The wooden coffins of the Sanauli royal burials provide another pointer to a possible Sintashta origin. The Sanauli finds are considered in the context of the author's archaeological model for the prehistory of the Indo-Iranian languages, which is adjusted to meet recent justified criticism.
\end{abstract}

In my book The Roots of Hinduism: The Early Aryans and the Indus Civilization (2015a), I proposed an archaeological model for the prehistory of the Indo-Iranian languages. ${ }^{1}$ In her constructive review of the book, Stephanie Jamison (2020) presented weighty criticism with regard to some of my central theses; in particular, she found the chronology involved much too long for the linguistic development of the Indo-Iranian languages. This has forced me to reconsider the model, with the result that I have found one central correlation - namely, that of the Proto-Iranian - to be fundamentally mistaken, and also from the archaeological point of view. In the following, I make the required adjustments to the model, which now works better than before. I also take the opportunity to clarify some of my conclusions more explicitly.

But we may begin with another point where Jamison has qualms:

1 I am grateful to Dr Albion M. Butters, Editor of Studia Orientalia Electronica, for checking my English and for speedy publication of this paper, and to two anonymous reviewers for their insightful suggestions.

Volume 8(1) (2020), pp. 175-198

DOI $10.23993 /$ store. 98032

Licensed under Creative Commons 4.0 (CC BY-NC-SA 4.0) license.

ISSN: 2323-5209

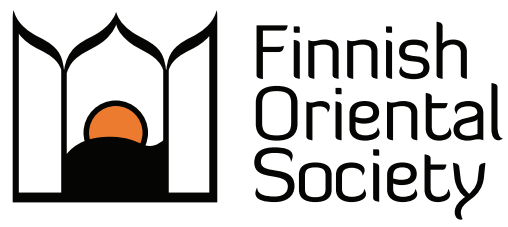




\begin{abstract}
We should now consider [...] the continuity he sees between the Indus civilization and post-Vedic Hinduism. First is the question by what mechanism Harappan concepts and practices could have been transferred to the Indo-Aryans, since the Indus civilization essentially ended in the very early second millennium BCE. It is a major conceptual leap from the undeniable statement that classical Hinduism differs in major ways from Vedic religion to the claim that much of what is non-Vedic in classical Hinduism should be attributed to the Indus civilization, whose flowering essentially ended at least 1500 years (approx. 1900 BCE [p. 22 and passim]) before "classical Hinduism" began (dated by Parpola to 400-200 BCE [p. 4 and passim]) and which inhabited a different geographical area from the core areas of post-Vedic Hinduism. This is, of course, the beauty of Parpola's (more or less invisible) first wave of Indo-Aryans, who arrived early enough to run across the last of Harappan culture, scoop up what they wanted, and carry it further into the subcontinent. It almost seems that the posited first wave exists in this schema primarily to be the conduit of Harappan materials into the later world of Hinduism. (Jamison 2020: 243)
\end{abstract}

Dramatic archaeological discoveries made after the appearance of my book - in the spring of 2018 - have now provided strong evidence for the arrival of the first wave of Aryan (IndoIranian) speakers to the Ganga-Yamuna doab by about 1900 BCE and for their forming then the ruling elite of a major Late Harappan settlement. I refer to the royal "chariot" burials excavated at the Late Harappan graveyard of Sanauli (also called Sinauli), District Baghpat, western Uttar Pradesh, just 60-70 km from Delhi. After these excavations, in July 2018, S.K. Manjul, the director of the Sanauli excavations, delivered in Delhi a lecture entitled "Mahābhārata and archaeology: PGW [Painted Grey Ware] vis-à-vis OCP [Ochre-Coloured Pottery]/Copper Hoard Culture", connecting the latter culture with the epic, while B.B. Lal has long argued for the Mahābhārata's connection with the PGW. (Agha 2018, which report also contains Agha's interview with B.B. Lal on Manjul's hypothesis; on the PGW and the Mahābhārata, see also Parpola 2015a: 145-149.) In the ensuing discussion (summarized by Agha 2018 and Benedetti 2020), Indian scholars have continued the debate about the finds' connection with the Mahābhārata war. Benedetti (2020: 258) notes:

\begin{abstract}
In fact, the new discoveries from Sanauli show us a warrior culture with swords and chariots, but this culture is not only typical of the Mahābhārata: also the Rgveda mentions battles, warriors, chariots (ratha) and spears (rstit). If the age of the Sanauli chariots is 1900-1800 BC it would correspond to the age of the early Rgveda according to our chronology. At last, we would have the concrete representation of the rathas of those ancient hymns.
\end{abstract}

\title{
THE LATE HARAPPAN GRAVEYARD OF SANAULI
}

A landowner from the village of Sanauli removed alluvial earth from his agricultural fields in an area of $35 \times 20 \mathrm{~m}$ to a depth of $1.5 \mathrm{~m}$. This digging exposed pottery remains, some other artefacts (including an antennae-hilted copper sword), and human skeletal remains. After a preliminary investigation of the find spot by a team of archaeologists in 2004 (Sharma et al. 2005), Excavation Branch II of the Archaeological Survey of India (ASI) carried out excavations at Sanauli in 2005-2006 (Sharma, Nauriyal \& Prabhakar 2007). The excavations exposed a large graveyard with 116 burials. In most cases, the heads of the skeletons are towards the northwest and the body extended towards the southeast. (On the body orientation, categories, and bioarchaeological findings of the burials, see Prabhakar 2012; 2013a: 82-87.) After a detailed analysis of the burial pottery from Sanauli, V.N. Prabhakar (2012; 2013a: 87-103) concludes that: "The burials of Sanauli cemetery $[. .$.$] contain a specific set of pottery containing jars,$ bowls, dish-on-stands, bowls-on-stands [...] a clear continuation from the mature Harappan burials in terms of general typology and arrangement of pottery has also been observed from 
the pottery types. The pottery assemblage from Sanauli cemetery is so far the largest category of late Harappan pottery from the Ganga-Yamuna doab." Prabhakar has also studied the 2,193 beads then found at Sanauli: 1,398 (63.758\%) of these are from burial contexts; "even though a considerable number of beads were found from secondary context, they belong to the late Harappan bead typology and hence can be firmly placed in the second millennium BCE context" (Prabhakar 2013b: 90). In the distribution of Late Harappan culture, the thickest concentration of sites is in the upper Ganga-Yamuna interfluve (Figure 1), where Sanauli is surrounded by a number of Late Harappan sites.

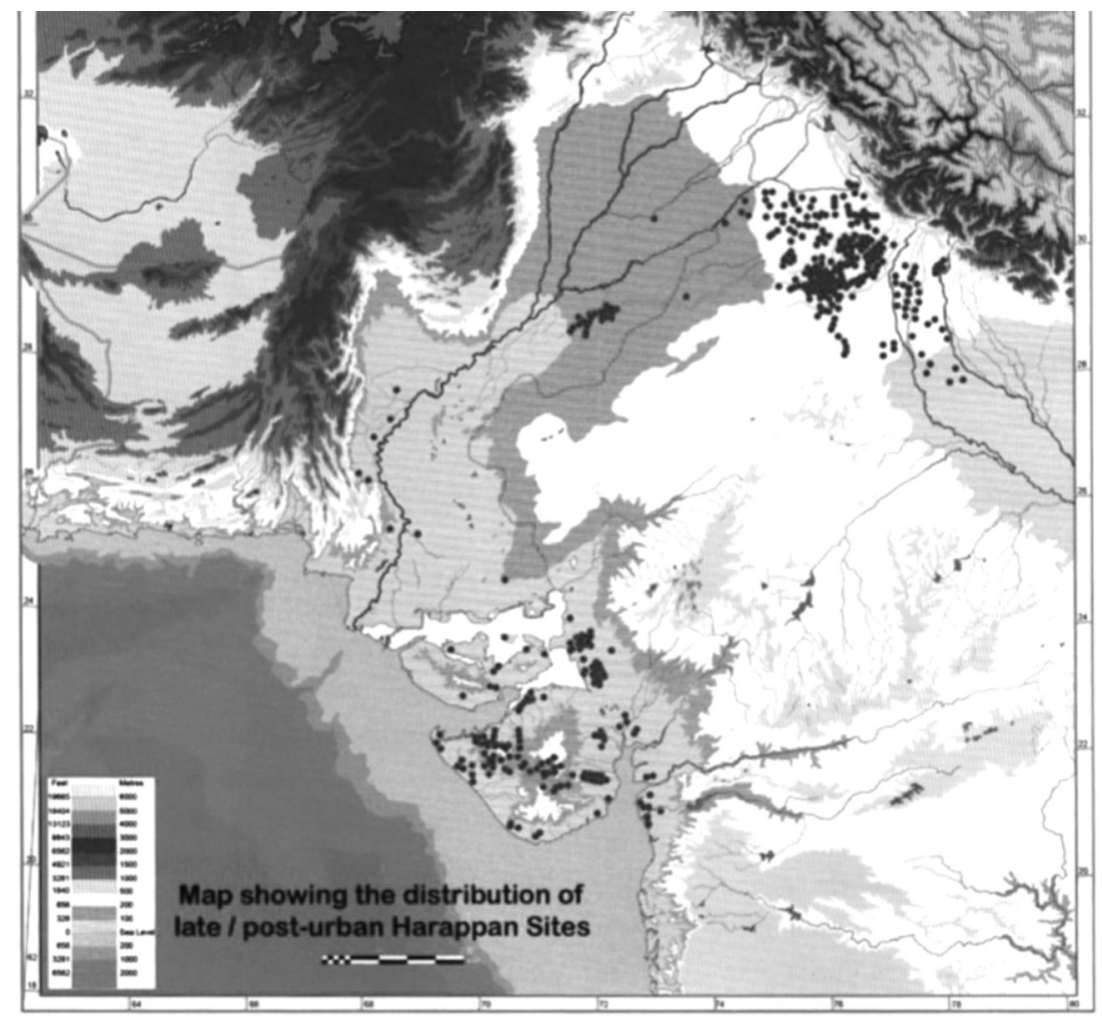

Figure 1 Distribution of the Late Harappan sites. After Prabhakar 2013b: 64, Fig. 1.

\section{THE ROYAL GRAVEYARD OF SANAULI WITH "CHARIOT" BURIALS}

The habitation site of Sanauli is likely to be a large one, perhaps even the capital town of the area, but its exact location is yet to be confirmed (pottery and hearths were found in a trial dig $800 \mathrm{~m}$ away in 2018). New excavations carried out in 2018 about a hundred metres from the previously excavated graveyard at Sanauli brought to light seven more graves in what is believed to be a royal cemetery. Again, the excavators were led to the spot by chance finds made by the villagers. Sanjay Kumar Manjul and Arvin Manjul (both of the Archaeological Survey of India), who directed the excavations, have so far published only a short preliminary report with 12 photographs (2018). Supplemented by T.S. Subramanian's interview (2018) made at the site while the excavation was still going on and illustrated with further photographs, and the ASI photos in Kumar (2018), one gets a good idea of the discoveries. These include two cart burials, the very first of their kind in India datable to the Bronze Age. 
A new mode of burial not found in the previously excavated graveyard of Sanauli is also attested in this royal cemetery, namely, inhumation in legged wooden coffins placed in large grave pits. The 30-35 mm thick wooden planks of the three coffins found have totally decomposed, but they could be identified as such because two of them had a copper plating (about $3 \mathrm{~mm}$ thick) all around.

There were two secondary burials in addition to that of the coffin Burial no. 3; one contained two persons. Furthermore, there were two cenotaphs without any human remains, but in one of them a bird and a dog were buried in the same pit. It should also be noted, "The pottery yielded in all burial pits were placed all around the dead, generally big pots kept near the legs and bowls and flasks arranged near the head indicating north-west direction" (Manjul \& Manjul 2018: 221). Benedetti (2020: 255) notes that the orientation of the bodies is thus the same as generally found in the Late Harappan graveyard, and adds that Vedic texts mention orientation of the burial towards the southeast, quoting Śatapatha-Brāhmaṇa 13,8,1,[5]: ubhe diśâv antareṇa vidadhāti prācīm ca dakșin̄ām caitasyām ha diśi pitṛlokasya dvāram. The following description concentrates on the coffin burials. DNA tests were taken of the human bodies in the Sanauli royal graveyard in 2018, but the results are pending, as they are being processed in the Deccan College, Pune, and a laboratory in Hyderabad (Dua 2020).

Burial pit no. 1 had a legged coffin (without copper coating) containing an almost intact skeleton of a tall woman in supine position. Around her elbow was an armlet of agate beads. Among the burial pottery stands out a big dish-on-stand on the floor of the pit on the left side of the skeleton, with a broken dagger and a bull-decorated comb made of horn (Figure 2) placed on this dish. There were also red vases with flaring rims (Figure 3), as in Burial pit no. 3, which clearly belong to the repertory of the OCP pottery. (Figure 4) A thin antennae-hilted sword was placed near the head in the north-western corner. Two long "channel-like copper objects" (Figure 5) with a semi-circular cross-section were beneath the coffin.

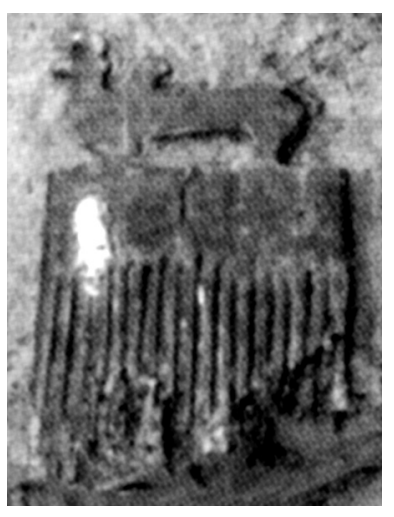

Figure 2 A bull-decorated comb made of horn from Burial pit no. 1. After Manjul \& Manjul 2018: pl. 5b.

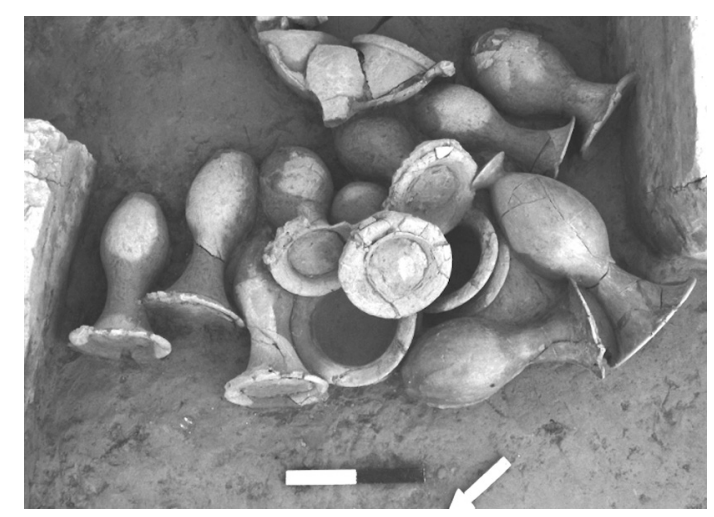

Figure 3 OCP vases in Burial pit no. 1. Photo Archaeological Survey of India, after Ahluwalia 2018.

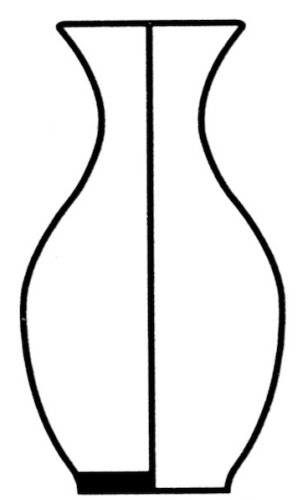

Figure 4 OCP vase type from Ambakheri. After Singh 2008: 217, Fig. 5.4. 


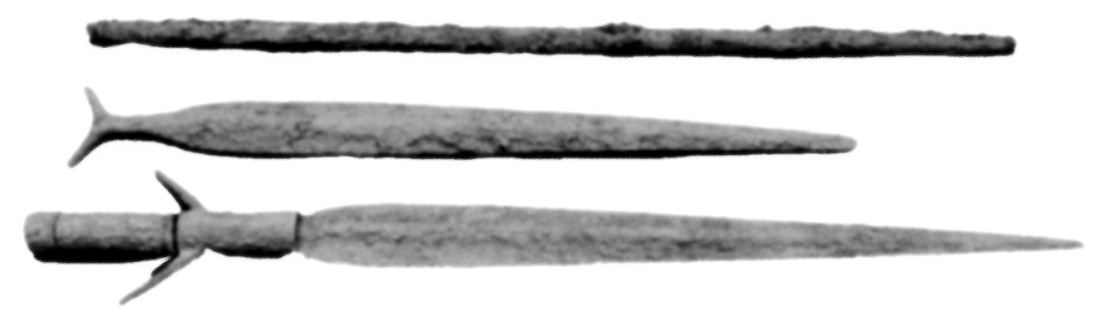

Figure 5 One of the two "copper channels" and two antennae-hilted swords - one $70 \mathrm{~cm}$ long with a unique wooden hilt covered with copper strips - from the cenotaph in Burial pit no. 5. After Manjul \& Manjul 2018: pl. 8.

The floor of Burial pit no. 3 had been covered with a mat made of dry reeds. A coffin (measuring $163 \times 72 \times 75 \mathrm{~cm}$ ) on four legs (each $44 \mathrm{~cm}$ long), having all over copper sheathing and decorations, was placed in the centre of the pit. A "chariot", a shield, a sword, a torch, a helmet, pottery, and other grave goods were around it. (Figure 6) This was a secondary burial with partial human bones placed in the coffin. The full-sized two-wheeled "chariot" in the south-east corner had suffered damage from recent agricultural work. One wheel, the pole, and the yoke were almost intact (Figure 7), but the other wheel, axle, chassis, and dashboard were partially damaged. Yet, it is clear that the "chariot" had a fixed axle, which supported a semi-circular wooden platform covered with thick copper plates; the platform was protected by side panels and a high dashboard in front. The platform was framed with copper pipes for fixing the side panels and one pipe for the attachment of an umbrella. (Figure 8) The inner and outer sides of both solid wheels were decorated with triangular copper sheets in three rows radiating from the central hub to the outer rim; they were fixed with $2 \mathrm{~cm}$ long copper nails (Figure 9). Similar copper triangles decorated the pole and the yoke. A bowl-shaped copper helmet was on the northern side of the coffin. Beneath the coffin were two long "channel-like" copper objects and a copper dagger, which had a wooden handle fixed with copper nails. Slanting on the pole of the "chariot" was a violin-shaped shield (possibly made of wood and leather), decorated with copper strips arranged in a checker pattern with four leaves in the centre. Placed over the yoke of the "chariot" were two objects, a torch having a deep copper pan and a long wooden handle covered with a copper sheath, and an antennae-hilted sword $(42 \times 5 \times 0.7 \mathrm{~cm})$. Hundreds of beads recovered from garland arrangements decorated the burial, with semi-precious stones on the human bones and bluish-green faience beads on the grave goods.

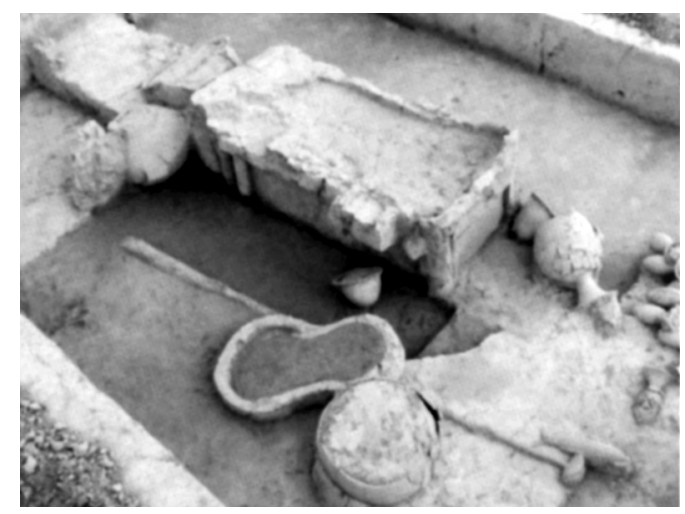

Figure 6 Burial pit no. 3 with wooden coffin, shield, "chariot" pole, torch, antenna sword, helmet, and other burial goods. After Manjul \& Manjul 2018: pl. 6.

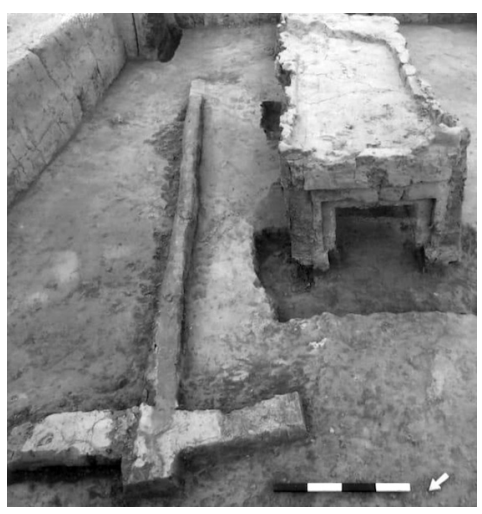

Figure 7 Burial pit no. 3. Coffin with "chariot" pole and yoke in situ. Photo: Archaeological Survey of India, after Kumar 2018: Fig. 10. 


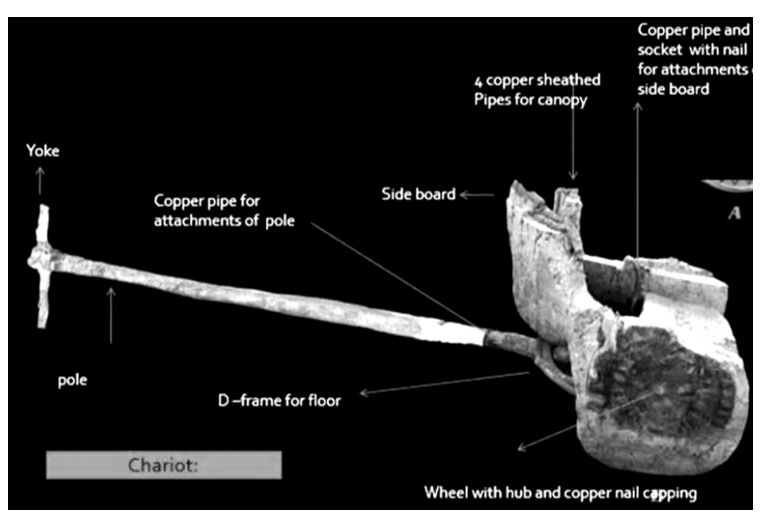

Figure 8 Structural details of the Sanauli "chariots". Image Archaeological Survey of India, after Dua 2020 .

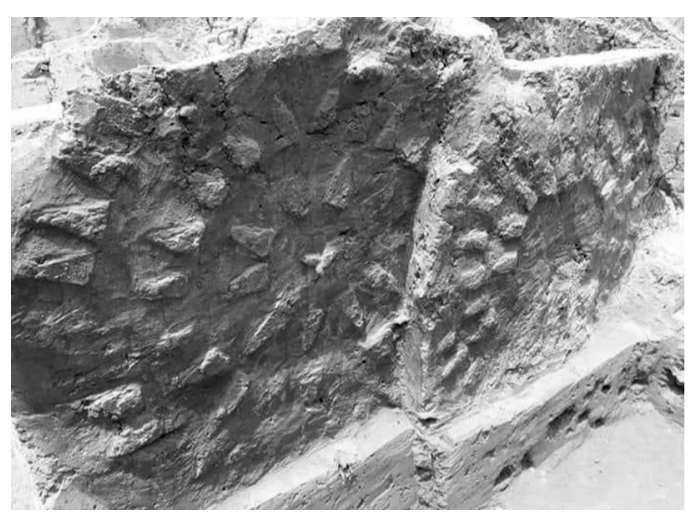

Figure 9 Close-up of wheels of the two "chariots" in Burial pit no. 6. Photo: Archaeological Survey of India, after Kumar 2018: Fig. 9.

Burial pit no. 6 contained a very large coffin (measuring $259 \times 72 \times 95 \mathrm{~cm}$ ) with four legs (each $50 \mathrm{~cm}$ long), having copper sheathing both inside and outside. The decoration consisted of copper strips and triangles, and a beautiful foliage design on the outer side. This burial pit contained a pair of two-wheeled "chariots" of the kind found in Burial pit no. 3. (Figures 10 \& 11) In addition, on the north side of the coffin there was a long copper-decorated shaft of a whip (without the decomposed lash of leather or thread). Other prestige objects included a helmet, a shield (of which only scanty evidence is preserved), and a chalice-shaped large solid copper bowl cast in one piece with a small stem and provided with a tortoise-shaped base (Figure 12). (The tortoise as the firm foundation belongs to the fundamental ideas of later Indian tradition and may be of Harappan origin.) Beneath the chalice were two caps made of electrum (a metal not otherwise known from Bronze Age India), probably for the two ends of a sceptre (Figure 13). The coffin was decorated with strings of gold beads, long cylindrical steatite beads, and white and greenish paste beads.

\begin{abstract}
The lid of the coffin is highly decorated and carved out in high relief. At the starting possibly a crown or royal insignia was depicted and followed by eight anthropomorph[s]. The high relief carving was done in wood and after that thin copper sheathing was provided with the help of small nails to fasten it. [...] A human skull has been exposed partially below the first and second anthropomorphic figures. All eight figures are depicted in similar style with minor deference in shoulder part and Aayudha holding in hand. The depiction is of a human, head adorned with the headgear of half rounded horn[s] turning inwards and probably a peepal leaf in centre. [Figure 14] Although the details of lower portion has [read: are] not comprehensible but in three figures they have [/] hold some object in their hand which may be the weapons (Aayudha) or some other object that belongs to the particular figure. These figures are one of the finest examples of wood and metal craftmanship. Due to corrosion it became fragile and very difficult to expose. It also provokes us to rethink about the origin of iconographic representation of divinity. (Manjul \& Manjul 2018: 224)
\end{abstract}

In the iconography of Mature Harappan seals, anthropomorphic figures wear fig leaves in their horned headdresses (Parpola 2015a: 234, Fig. 18.12; Joshi \& Parpola (eds) 1987: 76-77, 232; Shah \& Parpola 1991: 138-139). I am tempted to also see in these Sanauli images prototypes of the copper anthropomorphs (Figure 15), which are one of the hallmarks of the Copper Hoards in the Ganga-Yamuna doab, and which indeed could depict divinities. The paper-thin copper sheets covering the anthropomorphs on the lid of the royal coffin seem to give a functional explanation for the similarly paper-thin silver sheets depicting a bucranion or bull's head (with downturned horns, resembling the usually downturned arms of the anthropomorphs) in the Gungeria Hoard 
(Figure 16), and thereby suggesting an early date for this gigantic hoard from Madhya Pradesh. In his caption of our Figure 14, Subramanian (2018) notes that "another expert view is that the carving [of the eight images on the lid of the royal coffin] is of a bull head".



Figure 10 Sanauli royal coffin with two carts in Burial pit no. 6. Photo: Archaeological Survey of India, after Subramanian 2018.



Figure 11 One of the two carts in Burial pit no. 6. Photo: Archaeological Survey of India, after Subramanian 2018.

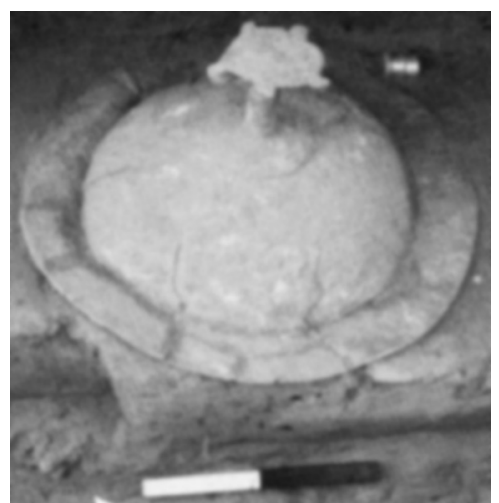

Figure 12 Tortoise-based copper chalice beneath the royal coffin in Burial pit no. 6. After Manjul \& Manjul 2018: pl. 9.

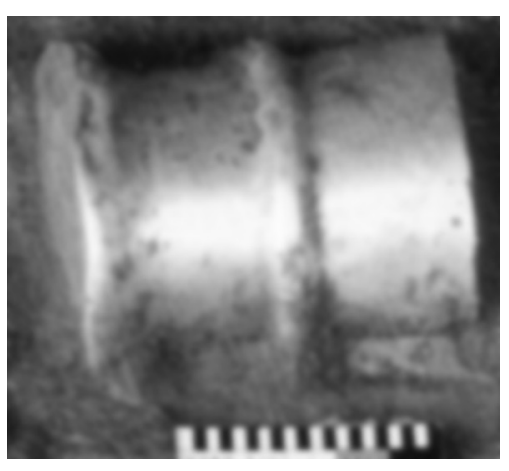

Figure 13 Sceptre top of electrum under the copper chalice (Fig. 12) in Burial pit no. 6. After Manjul \& Manjul 2018: pl. 10.

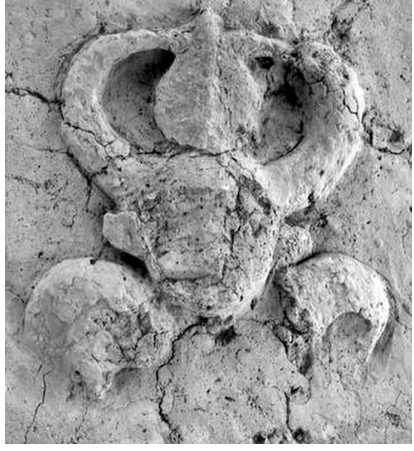

Figure 14 One of the eight "anthropomorphic figures" on the lid of the royal coffin in Burial pit no. 6. Photo: Archaeological Survey of India, after Subramanian 2018.

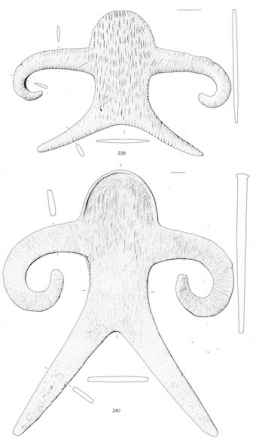

Figure 15 Two copper "anthropomorphs" from Bisauli, U.P. 23 x 35 x $0.7 \mathrm{~cm}(1.25 \mathrm{~kg})$ and $43 \times 38$ $\mathrm{x} 2.2 \mathrm{~cm}(6 \mathrm{~kg})$. After Yule 1985: pl. 11, nos. $239 \& 240$.
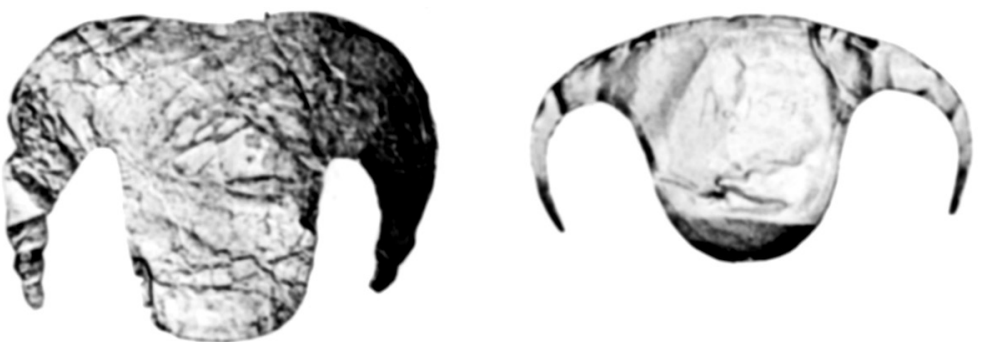

Figure 16 Two paper-thin silver bucrania in the Gungeria Hoard from Madhya Pradesh. $13.6 \times 10.1 \times 0.014 \mathrm{~cm}$, and $13.6 \times 7.7 \times 0.03 \mathrm{~cm}$. After Yule 1985: pl. H, nos. $522 \& 513$. 


\section{THE COPPER HOARD CULTURE}

The coffin burials of the royal graveyard at Sanauli suggest their association with the Copper Hoards, which have long been connected with the so-called OCP (Ochre Coloured Pottery) culture. OCP "is an ill-fired, wheel-made ware with a fine to medium fabric, and a thick red slip, sometimes decorated with black bands [...] The pottery was given its name because when it was rubbed, it left an ochre colour on the fingers" (Singh 2008: 216). OCP sites are mainly distributed in the Ganges-Yamuna doab, especially in western Uttar Pradesh - in the very same area where the majority of Late Harappan sites are found. At the royal cemetery of Sanauli, at least part of the funeral pottery is OCP (Figures $3 \& 4$ ). OCP has also been excavated at some other Late Harappan sites, such as Bargaon and Ambakheri. The OCP settlements are usually small (up to 300 square meters), rarely larger (e.g. Lal Qila, 632 square meters), and their deposits shallow (0.5 to $1.5 \mathrm{~m}$ ). The few structural remains found represent either wattle-and-daub houses or mud houses with wooden posts and frames. Artefacts other than pottery are also rare; they include querns, beads, and some Copper Hoard-type objects: a harpoon, a hooked spearhead, a celt, and an arrowhead. Terracotta artefacts recovered from Lal Qila included anthropomorphic and animal figurines, wheels, bangles, gamesmen, crucibles, grinders, and querns. Stratigraphically, the OCP level is followed either by a BRW (Black-and-Red Ware) level and then a PGW (Painted Grey Ware) level, or by a gap and a PGW level (Agrawal \& Kharakwal 2003: 209-211; Singh 2008: 216-217). The PGW (c.1100-350 BCE) can with good reasons be equated with the Middle and Late Vedic culture (see also Parpola 2015a: 145-148, with distribution map in Fig. 13.1).

\section{THE ANTENNAE-HILTED SWORDS}

Particularly diagnostic with regard to the Copper Hoard association of the royal graveyard at Sanauli are the many antennae-hilted swords found there. They are characteristic of the early Copper Hoards but absent from the Mature Harappan culture. One antennae-hilted sword (49.3 cm long) with its sheath was found already in 2005-2006 in the cenotaph Burial no. 14 from the lowest level of the Late Harappan graveyard of Sanauli (Sharma, Nauriyal \& Prabhakar 2007: 170). I have earlier compared the antennae-hilted sword (52 cm long), coming from looted graves of Bactria in Afghanistan and assigned to the BMAC (Bactria and Margiana Archachaeological Complex of southern Central Asia; see Amiet 1977: Fig. 17; Sarianidi 1986: 198, Fig. 75), to the similar swords of the Copper Hoards of India (Figure 17), suggesting a BMAC origin for the Copper Hoards. The finds of the royal graveyard of Sanauli have now been dated to around 1900 BCE.

ASI joint director S.K. Manjul, who led the excavations at Sanauli, told TOI [Times of India] that carbon dating has now confirmed that the burials date back to $1900 \mathrm{BC}[\ldots]$ A recent report submitted by the Birbal Sahni Institute of Paleosciences in Lucknow to the ASI had said that there are two C-14 (carbon dating) dates -3815 and 3500, with a margin of error of 130 years - for the Sanauli site. (Dua 2020)

Around 1900 BCE is also the date for the BMAC graveyards at Quetta and Sibri near the Bolan Pass, which connects Baluchistan with the lower Indus Valley (Jarrige 1991; 1995; Jarrige \& Hasan 1989; Jarrige \& Quivron 2008). Around this time, the BMAC expanded in many directions. (Figure 19) The Bolan Pass would suit as the main entrance of early BMAC-related people to the subcontinent, for antennae-hilted swords have been found not only in the Ganges-Yamuna doab, but also in Gujarat (Yule 1985: 92 \& pl. 98 nos. 1055-1057, 1060) and in the Deccan and South India. In fact, the antennae-hilts of the three swords from Kallur in Karnataka (Yule 1985: 91-92 \& pl. 97 nos. 1052-1054) provide the closest parallels to the sword from Bactria (Pottier 1984: 15). 
A similar sword was also found in 1982 at Shavinipatti village in Tamil Nadu (Yule 1989: 199 \& Fig. 7 no. 1086); in 2000 eight swords of the same type (Figure 18) were "unearthed by the quarry people from the eastern slope of the Ganganallur hill near the excavated [Neolithic] sites at Appukkal", Vellore District, Tamil Nadu (Kumar \& Rajan 2016: 61, with Fig. 7). D.P. Sharma (2002) has published many additions to Yule's monumental catalogue and studies $(1985 ; 1989)$ of the Copper Hoard objects, mainly from private collections and without any archaeological provenance; these additions include a number of antennae-hilted swords. It should be noted that the antennae-hilted swords differ from the swords of the Sintashta and related steppe cultures. They may have been inspired by West Asian swords, which were perhaps imported to the BMAC either from Syria and Anatolia or from Susa, as were many other cultural objects. For example, the inscribed dagger of the Kassite king Kadashman-Turgu (c.1281-1264) illustrated in Stol \& Seidl (2015: Fig. 1) resembles the antennae-hilted swords more than the steppe swords.

As Singh (2008: 219) observes, "A comparison of the Harappan copper artefacts and the copper hoard objects shows striking differences in typology and alloying techniques. About 46 per cent of the copperhoard objects had up to 7 per cent arsenic alloying. On the other hand, only 8 per cent of analysed Harappan artefacts show arsenic alloying". This statement is based on analysis of 41 Copper Hoard objects from Uttar Pradesh and Bihar (Agrawal 1971; Agrawal et al. 1974; 1978; Nautiyal, Agrawal \& Krishnamurthy 1981; Agrawal \& Kharakwal 2003: 201-206). In his analysis of 79 Copper Hoard objects, Andreas Hauptmann (1989: 264) noted, however, that "the amount of arsenic is generally so low as to be regarded as a common impurity in the copper [...] Five artefacts with an arsenic content of 3-5\% [...] could be deliberately produced alloys [...] arsenic-copper is especially suitable for smithing. As opposed to tin bronze which is used mainly for casting, arsenic-copper may be heated several times in a smithing hearth without changing its properties." It seems significant that an antennae-hilted sword from Rewari in Haryana is among Hauptmann's artefacts with a high arsenic content (3.2\%). Also another antennae-hilted sword from Sadabad (near Mathura in U.P.) had 2.54\% arsenic (Agrawal \& Kharakwal 2003: 204). Arsenical bronze is a "hallmark of all the farming cultures of Central Asia" (Kuz'mina 2007: 286). Of the steppe cultures, it is characteristic of the Sintashta culture: "In Sintashta $48 \%$ of the artifacts were made of copper with artificial arsenic admixture, and 34\% was of copper with natural arsenic admixture" (Kuz'mina 2007: 86). The use of arsenical bronze was low, however, and tin-bronze dominated in the successor cultures of Sintashta, namely the Petrovka and Alakul' cultures (see R. Doonan in Kupriyanova \& Zdanovich 2015: 188-194).

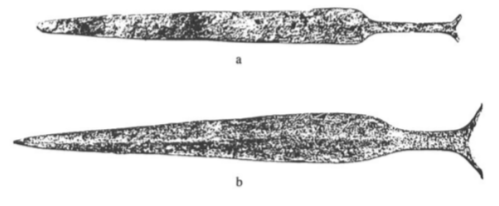

Figure 17 An antennae-hilted sword (a) from Bactria $(52 \mathrm{~cm})$ and (b) from Fatehgarh, Uttar Pradesh $(63.5 \mathrm{~cm})$. After Parpola 1988: 285, Fig. 10.

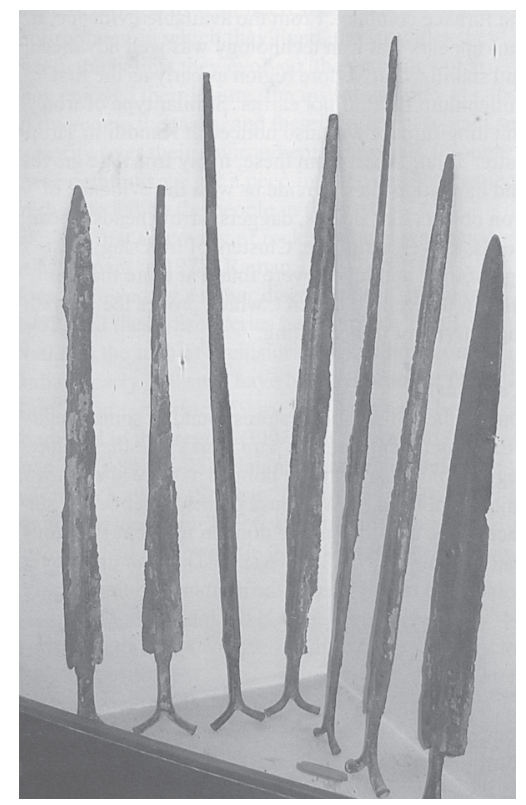

Figure 18 Antennae-hilted swords (measuring between 60 and $85 \mathrm{~cm}$ ) from the Vellore District of Tamil Nadu, now in the Vellore Museum. After Kumar \& Rajan 2016: 61 Fig. 7. 


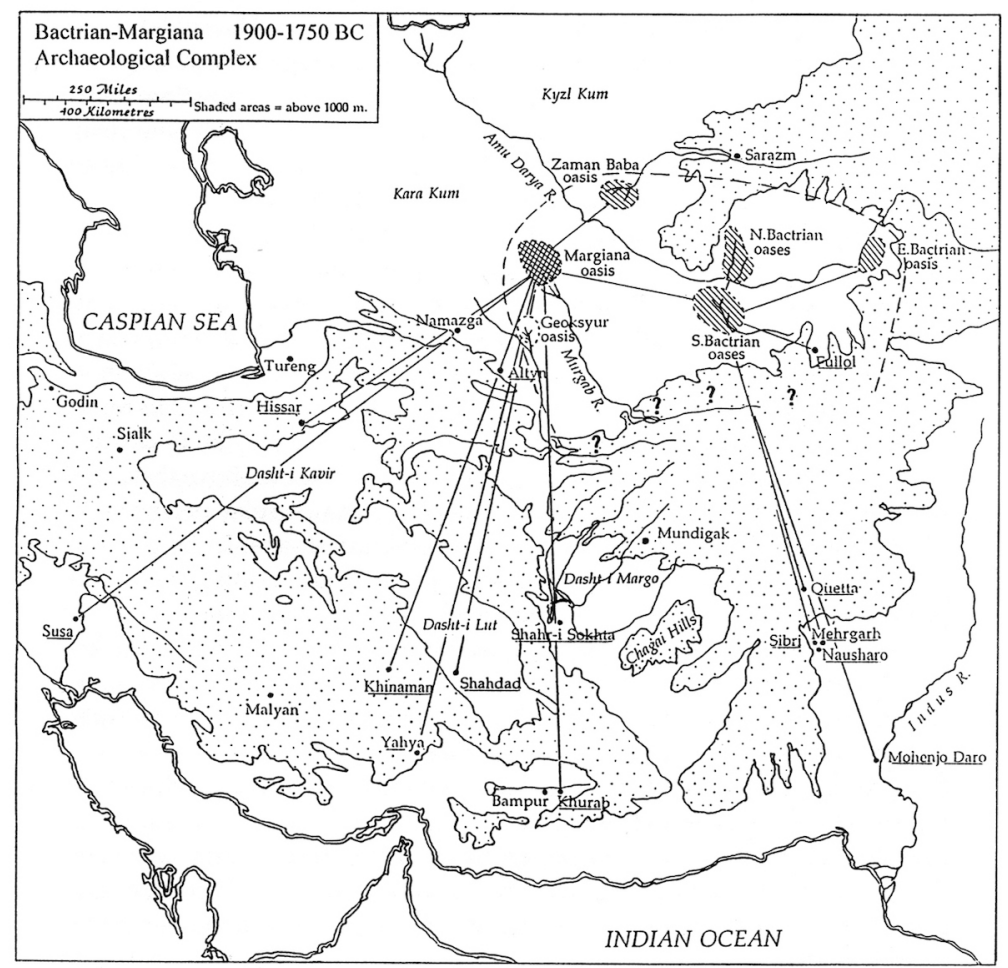

Figure 19 BMAC expansion around 1900-1750 BCE. After Hiebert 1994: Fig. 10.8.

\section{THE SANAULI "CHARIOTS"}

In a newspaper interview in February 2018, the excavator S.K. Manjul was asked: "Were these chariots driven by horses?" He replied: "The size and shape of the chariots indicate they were pulled by horses. The axle, chassis and wheels show similarities to the contemporary chariots" (Yaajnaseni 2018). Historians of the vehicle technology reserve the term chariot for "a light, fast, two-wheeled, usually horse-drawn, vehicle with spoked wheels; used for warfare, hunting, racing and ceremonial purposes. Its crew usually stood" (Littauer \& Crouwel 1979: 4-5; 2002: xvii). The reservation "usually horse-drawn" took into consideration early two-wheelers of ancient Mesopotamia, which were drawn by other equids: the hemione and ass. Nowadays this reservation is omitted, the horse being an essential part of the chariot definition:

The invention, development and primary use of a new vehicle which unlike the earlier ox-drawn wagon or cart took advantage of a novel tractive force, the domesticated horse, coupled with the construction of a light, strong two-wheeled car for one or two persons which would enable the horse's agility and swiftness to be exploited and achieve the hitherto unfulfilled psychological excitement of speed in motion. This combination of swift motive power and a vehicle appropriate to its employment, however used, was the chariot. (Piggott 1992: 42)

The technological requirements of the chariot as a structure apart from its motive power are less complicated [...] The qualities sought for were lightness and strength to meet requirements, notably speed, unattainable by the disc-wheeled wagon or cart drawn by oxen, or donkeys or mule-type hybrids, and this was obtained [...] by using bent wood to form, with skilled jointing techniques, glue, leather and metal, a light resilient freely moving vehicle with two spoked wheels. (Piggott 1992: 44-45) 
There is a growing consensus that the horse-drawn chariot was developed in the Sintashta culture of the southern Trans-Urals, and that this happened close to 2000 BCE (Anthony \& Vinogradov 1995; Kuz'mina 2003: 217-225; Sherratt 2003: 244-247; Kuznetsov 2006). The Sintashta excavations have shown that a vital part of the chariot's invention was also the creation of a fitting harness - including cheek-pieces (psalia) made of bone or horn which enabled effective control of the chariot horses. The subsequent development of the cheek-pieces has enabled charting of the geographical spread of the chariot and its chronology (Kuz'mina 2007: 109-131; Kuznetsov (ed.) 2010; Kupriyanova et al. 2017).

The "chariots" of Sanauli do not have spoked wheels but solid ones, which would have been too heavy to be pulled by horses. That they actually were bull-drawn, two-wheeled carts is suggested also by the absence of horse skeletons or horse skulls, of the cheek-pieces used in driving the early horse-drawn chariots, and by the absence of the horse in the imagery of the Sanauli finds, which is dominated by the bull. A humped bull decorates the comb excavated there (Figure 2). In addition, the anthropomorphic figures on the coffin lid at Sanauli wear bull's horns (Figure 14); their parallels in the Gungeria hoard are bucrania (Figure 16). Further, the three vehicles of the Sanauli royal burials can be compared with the copper sculpture of a cart and its rider pulled by two humped bulls from the Late Harappan site of Daimabad in Maharashtra (Figure 20). The extraordinary hoard of Daimabad comprises four bronze sculptures together weighing over $60 \mathrm{~kg}$ (Yule 1985: 10-12, 29-31 and pl. 2-4 nos. 36-42). According to Yule (1985: 29), "Based on the information supplied by the Bhils who accidentally discovered [the hoard], as well as with the help of stratigraphic investigations, the findspot seems to lie in the Late Harappan levels of section III." Although unique, the Daimabad sculptures may be counted among the Copper Hoards, which in several cases similarly contained great amounts of copper; the largest one, coming from Gungeria in Madhya Pradesh, consisted of 526 copper and silver objects weighing together $377 \mathrm{~kg}$ (Yule 1985: 1). The Daimabad cart is described by Yule (1985: 30-31) as follows (this is only a part of his detailed description of the object):

\begin{abstract}
The chariot floor is formed of a diamond-shaped platform from which a socketed rod extends to meet the pole. Flanking the platform, two anvil-like side panels extend downwards as axle struts and stand erect to form the superstructure. Issuing from the front parts of the panels a chevronshaped cross member connects both sides of the chariot. At chest height of the charioteer the sides are joined by another horizontal member and rods converge at the front onto the back of a dog, which is posed standing on the pole. In his right hand the charioteer holds a curving whip, the upper surface of which is cross-hatched.
\end{abstract}

The Indus Civilization had bull-carts (Kenoyer 2004) - their Sanskritized Dravidian name śakaț- (from Proto-Dravidian * cațtakam) gradually replaced its Indo-European synonym anas in the Vedic texts (Parpola 2019a) - but no cart burials are known from the Mature Harappan culture. Without any predecessors in South Asia, the Sanauli cart burials are likely to be derived from an external origin.

[O]ver the great area of steppe from north-east Bulgaria to the Volga, vehicle burials have been excavated in soil conditions which have enabled the recovery of whole wagons or of wheels, as well as pottery models of carts, though never of the draught animals, which were not included in the burial. These burials belong to a consistent culture and date from about 3000 to 2500 BC. These are the earliest vehicle burials in prehistory. (Piggott 1992: 20)

The Yamnaya or Pit Grave culture, to which these earliest vehicle burials belong, is nowadays widely considered to represent the culture of Late Proto-Indo-European speakers (Mallory 1989; 
Anthony 2007). This correlation has been reinforced by studies of ancient DNA, which connects the spread of the R1 haplotype with the dispersal of the Yamnaya culture into the areas where IndoEuropean languages are first attested (Haak et al. 2015; Reich 2018). With the invention of the horse-drawn chariot, it replaced the ox-cart as "the vehicle of prestige - the only approved conveyance for the chieftain and his noble entourage in ceremony and ritual, hunting and its counterpart, warfare" (Piggott 1992: 56). In both cases, the vehicles "play a symbolic rôle in the burials of an upper stratum of society, reflecting their prestige as carriages for the living" (Piggott 1992: 37-38).

The chariot was preceded by the bull-drawn cart with solid wheels, known from the Yamnaya and Catacomb culture burials of the Pontic steppes, such as Kurgan 11, burial 27 at Mar'evka on the Dnieper River in Ukraine (Figure 21) (Pustovalov 1994; 2000; 2008; Kuz'mina 2003: 214). The Sanauli and Daimabad cart riders may represent early immigrants, who had come to South Asia via the BMAC from the early phase of the Sintashta culture, when the spoke-wheeled and horse-drawn chariot had not yet been invented. At Sintashta, a cart with two tripartite wheels has been reconstructed for Grave 16 stratified beneath Grave 10 (which contained the skeletons of two horses) in the burial complex SM (Gening, Zdanovich \& Gening 1992: 144-155, Figs. $65 \& 72$ ). A cart with solid or tripartite wheels would have been pulled by bulls - and in Grave 16 the draught animals are missing in the old Yamnaya fashion, as they are in the Sanauli burials. A two-wheeled cart with solid wheels ridden by one man and drawn by two galloping bulls is depicted on a silver cup without provenance but ascribed to the BMAC (Figure 22). The galloping of the bulls testifies to fascination with speed and racing, which must have been the primary motif for developing the horse-drawn chariot. A chariot race is the main constituent of the Vedic vajjapeya ritual (Sparreboom 1985: 28ff.). An intermediate phase from the heavy solid or tripartite wheel to the light spoked wheel is the cross-bar wheel, which is already light enough to be drawn by horses (Littauer \& Crouwel 1977), and such a "proto-chariot" is depicted in a BMAC-related cylinder seal from Tepe-Hissar III B (c.2000-1900 BCE) (Figure 23). A non-Harappan type of axe-adze characteristic of the BMAC (also at Tepe Hissar III C) was found from the last phase (c.2000-1900 BCE) of Mohenjo-daro (Wheeler 1968: 74, Fig. 12 nos. 13, 75, 124; Parpola 2015b). A disturbed elite grave at Zardcha-Khalifa in Tajikistan contained much BMAC pottery, a horse-headed bronze pin or sceptre, a pair of cheek-pieces of the Sintashta-Petrovka type, and a unique pair of bronze bits (Figure 24). Thus, the BMAC elite had horse-drawn chariots derived from the Sintashta culture by 1800 вСE.

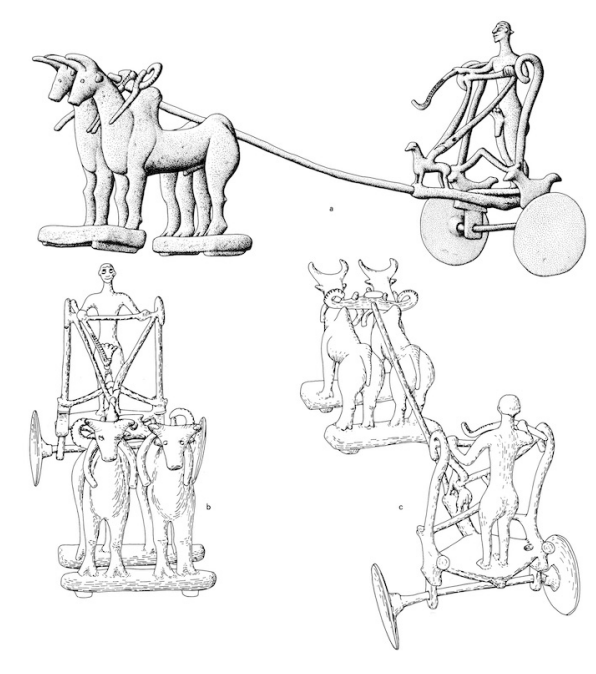

Figure 20 Copper sculpture of a bull-cart from Daimabad, Maharashtra. 24 x 16 × $26.5 \mathrm{~cm}(9.8 \mathrm{~kg})$. After Yule 1985: pl. 4 , no. 39 a-c. For a very detailed description of the whole sculpture and metal analyses of its various parts, see Yule 1985: 30-31. 



Figure 21 Reconstructions of two carts from the Tyagunova Barrow at Mar'evka on the Dnieper River in Ukraine, belonging to the Catacomb Grave culture. After Pustovalov 2008: 103, Fig. 2 nos. 4 \& 5.

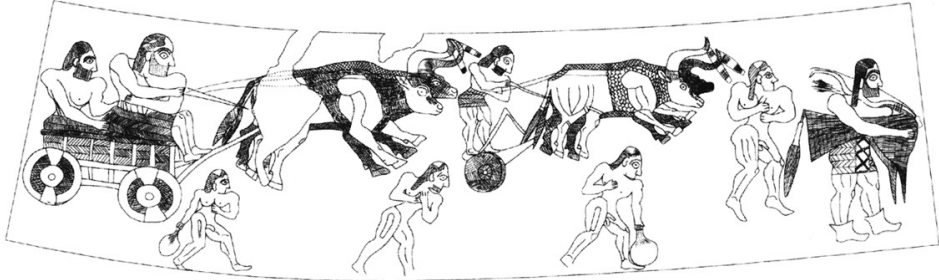

Figure 22 A BMAC silver cup depicting inter alia a race-cart pulled by galloping bulls. Musée du Louvre, AO 28518, drawing H. David, after Francfort 2005, Fig. 6.
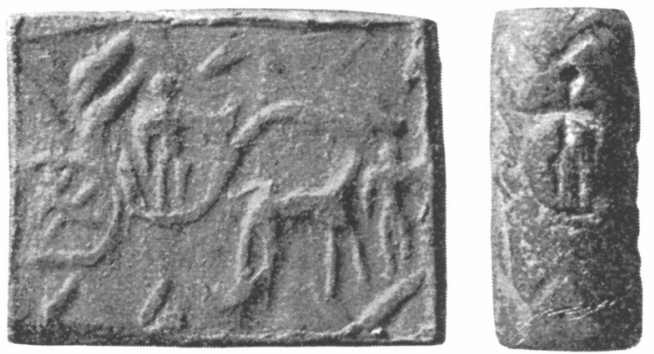

Figure 23 Cylinder seal from Tepe Hissar (Iran), Period III B, depicting a horse-drawn "proto-chariot" with cross-bar wheels. After Schmidt 1933: pl. cxxx, B (Schmidt 1937: 198, Fig. 118).
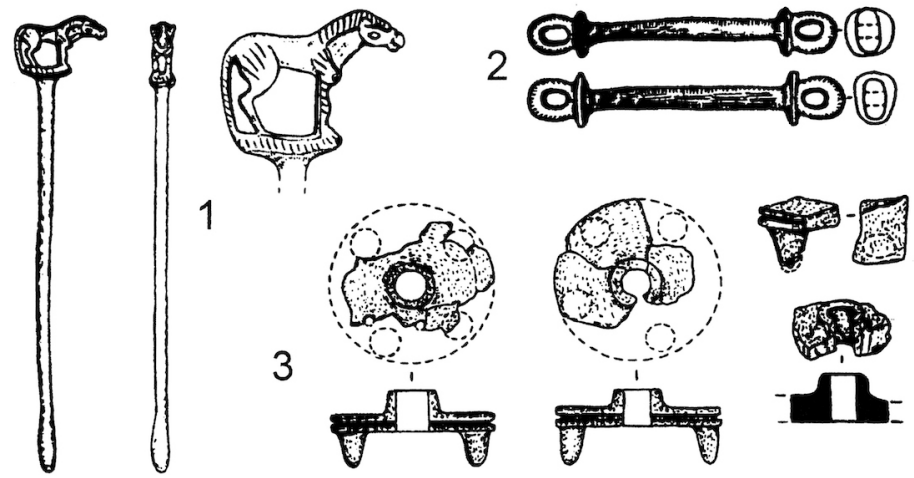

Figure 24 Finds from a BMAC elite grave at Zardcha Khalifa in Tajikistan. After Parpola 2015a: 78, Fig. 8.4, based on Bobomulloev 1997.

The Jaiminīya-Brāhmaṇa $(2,103)$, while discussing the Vedic soma sacrifice called apaciti 'veneration, respect' (which probably reflects the "preclassical" ["Atharvavedic"] ritual tradition), gives the following description of a Vedic elite chariot (not in Sparreboom 1985) as its priestly honorarium:

tasyāśvarathaś caturyug dakșinā bhavati / sarve śatakriyo 'śvāh / sa rukmī prāvepī sarvābharany à்śumān bhavati / tasya vaiyāghrah parivāro bhavati dvaipo dhanvadhir ārkșa upāsañgah / khādgakavaco 'dhyāsthātā bhavati saṃnaddhas saṃnaddhasārathir āvṛtaḥ pratihitābhyām / niṣkī sragvī samgrahìtā bhavati / 
Its priestly honorarium consists of a horse chariot pulled by four horses each worth a hundred cows. The chariot is provided with golden plates, with a whip, with all sorts of ornaments and with splendour. Its deck is covered with tiger skin, its bow-case with panther skin, its quiver with bear skin. The warrior standing on it is equipped for battle, wearing armour made of rhinoceros skin; he has a charioteer equipped for battle, and is protected by the two side panels [?]. The rein-holder wears a neck ornament and a garland.

(For parallel passages in younger Vedic texts, other translations - pratihita, translated above as 'side-panel [of the chariot]' is usually rendered '[arrow] put on [a bow-string]', which does not make much sense here - and the interpretation of prāvepá- = prākāśa- as 'whip', see Parpola 2018.) The mention of the gold plates and decorations of the chariot can be compared with the ornamentation of the Sanauli carts with copper plates. Yet such decorations are widely mentioned in chariot descriptions (for instance, in early Greek, Roman, and Irish literature), so the parallel does not necessarily imply a continuation of tradition.

\section{THE SANAULI WOODEN COFFINS}

One pointer to the Sintashta culture as the ultimate source of the Sanauli carts is the wooden coffins of the royal burials. A few burials in wooden coffins are known from graveyard R 37 from Harappa belonging to the last phase 3D of the Mature Harappan period (Wheeler 1947: 87-88, Burial 5; Meadow (ed.) 1991: 195 \& 200, Fig. 13.11, Burial 147a; Prabhakar 2012: 209-211, 610-611). Besides Harappa and Sanauli, such burials in wooden coffins seem not to be known from other Mature or Late Harappan sites; at least from the relatively large Mature Harappan graveyards of Kalibangan (Lal et al. 2015: 8-9) and Farmana (Shinde 2011), and from the unusual cemetery at Dholavira (Bisht 2015: 628-663), no burials in wooden coffins have been reported. In the large graveyard of the BMAC capital Gonur, 2,853 graves had been excavated by 2007 . No burials with wooden coffins have been identified, but the "chamber tombs" $(1.9 \%)$ having brick walls and representing living houses - or, more exactly, their bedrooms - are thought to reflect Indo-Iranian traditions (Sarianidi 2007: 20-51).

In the Sintashta culture (c.2100-1800 BCE) of the southern Trans-Urals, the dead were buried in large rectangular pits inside of which was a rectangular wooden burial chamber. Bodies were most often lying on the side in a slightly flexed position, or on their back with their legs bent at the knees. There are also secondary and multiple burials. Grave goods are often abundant, containing many vessels, tools, and weapons of arsenical bronze, grindstones and pestles, animals (horses, cows, sheep, dogs), and in elite graves spoke-wheeled chariots and bridle cheek-pieces. (Gening, Zdanovich \& Gening 1992: 391-392 and passim.) In the earliest layers of the Bolshekaraganskij cemetery representing the Sintashta culture, the pottery had features from the earlier Abashevo (c.2300-1850 BCE) and Poltavka/Late Yamnaya (c.2500-2100 BCE) cultures, while in the late layers certain features point to the formation of the Srubnaya culture (c.1850-1450 BCE) (Zdanovich (ed.) 2002: 207). The immediate successor of the Sintashta culture in the Trans-Urals and Kazakhstan is the Petrovka culture (c.2000-1800 BCE), which soon diverged into the Alakul' culture (c.2000-1700 BCE) in the west and the Fëdorovo culture (c.1850-1450 BCE) in the east. All these branches of the Andronovo cultural community, which occupied the Asiatic steppes from the Urals to western Siberia between about 2000 and 1500 BCE, had the horse-drawn chariot inherited from the Sintashta culture. (Kuz'mina 2007) 


\section{THE SRUBNAYA (TIMBER GRAVE) CULTURE}

Between $c .1850-1450$ BCE, the Srubnaya culture dominated the East European steppe and foreststeppe in two closely intercommunicating varieties, the northern Pokrovskaya and the southern Berezhnovka-Maevka. (Figure 25) The latter resulted from the fusion of the Pokrovskaya with the Catacomb-based Babino-III culture, which had multi-roller (Russian: mnogovalikovaya) ceramics (c.2100-1850 BCE) on the Pontic steppe (Otroshchenko 2003: 319-320). It is from the Srubnaya culture - including its more north-westerly offshoot Pozdnyakovo culture (c. 1850-1450 BCE) in the Volga-Oka interfluve - that the Finno-Ugrian languages are likely to have acquired their early Iranian loanwords.

In The Roots of Hinduism, I wrote:

In the Late Bronze Age (c. 1500-800 BCE), the Srubnaya culture was followed by a number of cultures distinguished by roller pottery (Russian valikovaya keramika) (Fig. 9.7) [here Figure 26]. With their adoption of riding about $1500 \mathrm{BCE}$, the peoples of the roller-potter cultures were powerful warriors who enlarged the earlier Srubnaya area westwards, northwards and eastwards. In the east, roller-pottery cultures came to cover the whole of Kazakhstan and Turkmenistan [...] All of these roller-pottery cultures were the immediate ancestors of the Iranian-speaking mounted horsemen known as Scythians, Sarmatians, and Sakas, who ruled the Eurasian steppes from the Danube to Mongolia in the first millennium BCE and the early first millennium CE. Many of the river names in the European steppe have an Iranian etymology; for example, Don (and its diminutive Donets) comes from Old Iranian (Avestan) dānu, "river," which is also behind the initial part of the river names Dnieper and Dniester. (Parpola 2015a: 54)

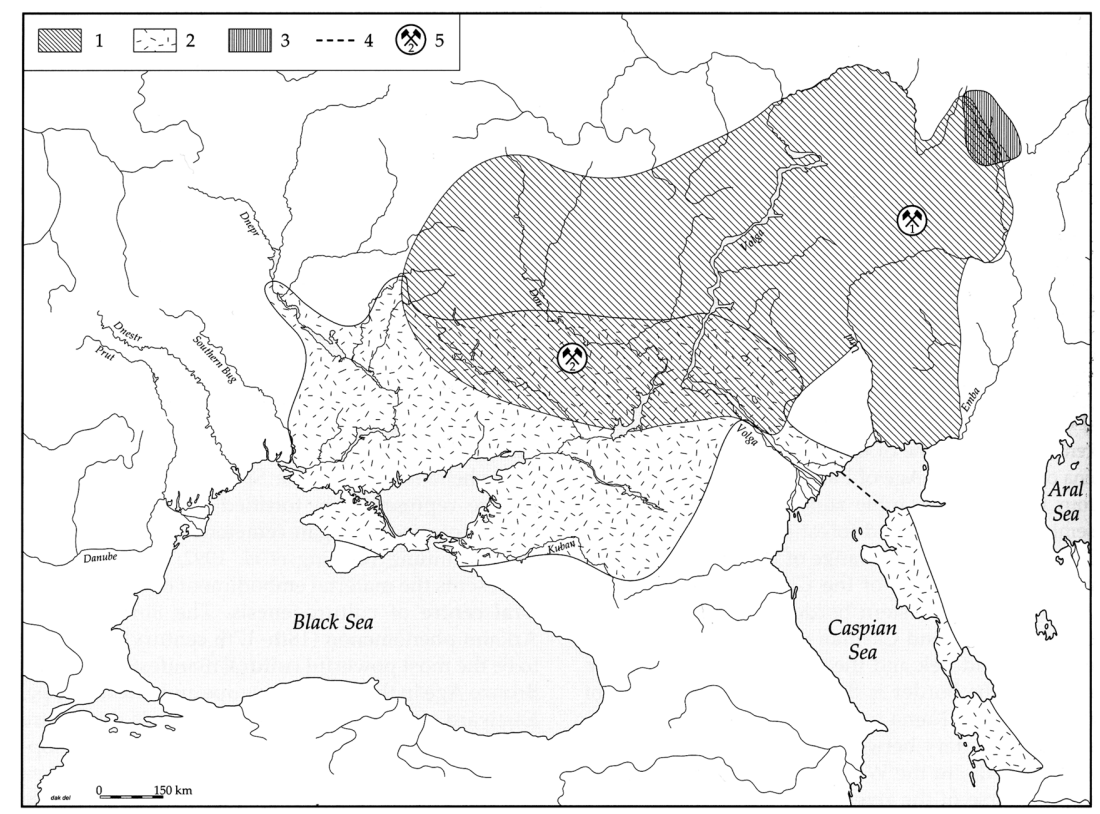

Figure 25 Diffusion of the Srubnaya (Timber Grave) culture according to Otroshchenko 2003: 320, Fig. 21.1 - (1) Pokrovskaya, (2) Berezhnovka-Maevka, (3) Sintashta and related cultures. 


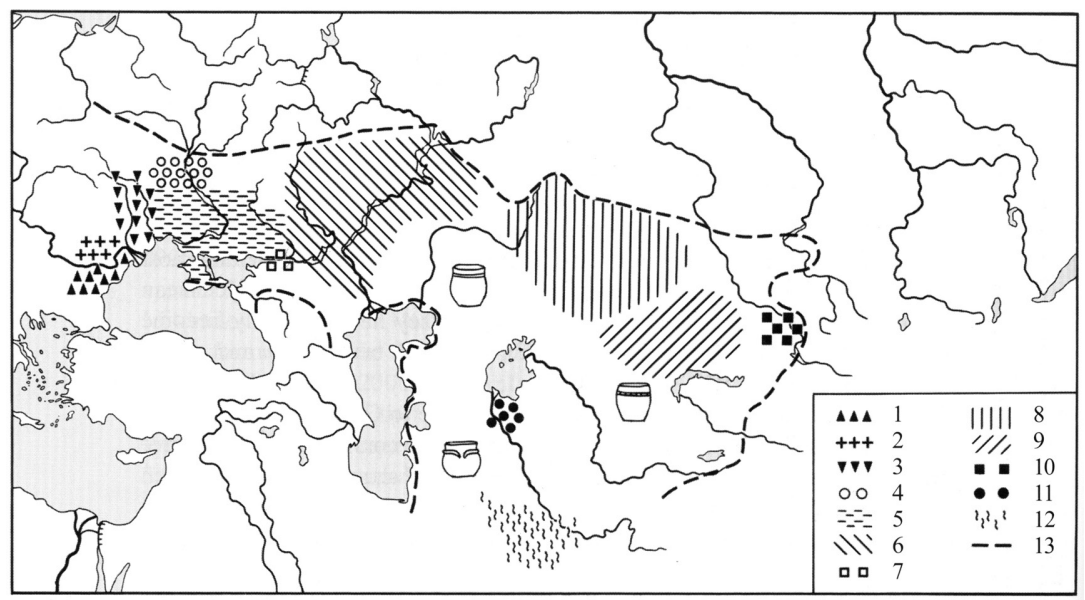

Figure 26 Distribution of "Roller Pottery" cultures. After Parpola 2015a: 105, Fig. 9.7, based on Chernykh 1992: 236, Fig. 79.

\section{THE ARCHAEOLOGICAL IDENTIFICATION OF PROTO-IRANIAN CORRECTED}

In my archaeological correlation of Proto-Indo-Iranian and its branching presented in The Roots of Hinduism (2015a) and elaborated further in Parpola 2017, I rashly assumed that the Srubnaya culture descended from the Catacomb culture, which prevailed in the Pontic steppes for the most part of the third millennium BCE, while the Catacomb culture descended from the Yamnaya (Pit Grave) culture nowadays widely recognized as the culture of Late Proto-Indo-European speakers. On the basis of this faulty assumption, I placed the separation of the Iranian and Indo-Aryan branches about one millennium too early. The exact origin of the Srubnaya culture continues to be debated, but so much is clear that it derives either from the Sintashta culture or from the related cultures of the Volga steppes, from which it inherited also its "Timber grave" (Kuz'mina 2007: 349-358; Otroshchenko 2003). The Srubnaya culture is closely similar to the Andronovo cultures, and there was a constant contact between them. I am revising my archaeological-linguistic correlations by placing the end of the Proto-Indo-Iranian period to around the twentieth century BCE, when the Sintashta and related cultures of the Volga-Ural steppes developed into the Proto-Iranian-speaking Srubnaya cultures of Eastern Europe and into the Proto-Indo-Aryan-speaking Andronovo cultures of the Asiatic steppes. This was also the basic conclusion of Elena Kuz'mina (2007).

\section{EARLY PROTO-INDO-IRANIAN}

Both the Andronovo and the Srubnaya cultures had from the beginning the horse-drawn chariot, which seems to have been invented in the "classical" phase of the Sintashta culture around late twenty-first century BCE. People of the earlier related cultures - the Abashevo, Poltavka, Sintashta, and Potapovka - would then have spoken Early Proto-Indo-Iranian. Based on the faulty correlation of Proto-Iranian with the Catacomb Grave culture, in The Roots of Hinduism I proposed a Proto-Indo-Aryan correlation for the Abashevo culture and the associated Sejma-Turbino trading network. Of all the potentially Indo-Iranian cultures, the Abashevo culture was the first to arrive to the Kama and Belaya Valleys immediately west of the Ural Mountains, the most likely domicile of Proto-Uralic speakers. The Proto-Indo-Aryan correlation of the Abashevo culture made it difficult 
to explain where the Finno-Ugrian languages could have obtained some Aryan loanwords that clearly represent Early Proto-Indo-Iranian, like Proto-West-Uralic *kekrä, 'circular thing, cycle', against Late Proto-Indo-Iranian *cakra-, 'wheel, cycle' (Holopainen 2019: 118-119, 336). An Early Proto-Indo-Iranian correlation of the Abashevo culture dissolves this problem. It must be noted that perhaps two centuries after the Abashevo culture came to the Kama-Belaya Valley, this area was reached also by a northward extension of the Alakul' Andronovo culture (mainly spread in the South Urals and Kazakhstan), descended from the Petrovka culture, while the Srubnaya culture arrived in these regions about the same time.

\section{SUCCESSIVE WAVES OF ARYAN-SPEAKING IMMIGRANTS TO SOUTH ASIA}

In the post-urban phase of the BMAC, practically all BMAC settlements in southern Turkmenistan were surrounded by pastoralist campsites having late Andronovo ceramics (Gubaev, Koshelenko \& Tosi 1998). South of this region, however, neither Andronovo pottery nor barrows typical of the steppe cultures have been found anywhere. Yet, Indo-Aryan languages originally spoken in the northern steppes had reached the Mitanni kingdom of Syria and South Asia by the middle of the second millennium. It therefore seemed logical to assume that the early Indo-Aryan speakers, who had arrived at the BMAC during its urban phase, had adopted this impressive culture wholesale (as they did in the Mitanni kingdom) and continued their southward spread in the garb of the BMAC culture (Parpola 1988; Mallory 1998; 2002; Hiebert 1995).

This hypothesis is supported by the recent study of "genome-wide ancient DNA data from 523 individuals spanning the last 8000 years, mostly from Central Asia and northernmost South Asia" by V.M. Narasimhan et al. (2019a; 2019b):

\footnotetext{
The movement of people following the advent of farming resulted in genetic gradients across Eurasia that can be modeled as mixtures of seven deeply divergent populations. A key gradient formed in southwestern Asia beginning in the Neolithic and continuing into the Bronze Age, with more Anatolian farmer-related ancestry in the west and more Iranian farmer-related ancestry in the east. This cline extended to the desert oases of Central Asia and was the primary source of ancestry in peoples of the Bronze Age Bactria Margiana Archaeological Complex (BMAC). [...] The main population of the BMAC carried no ancestry from Steppe pastoralists and did not contribute substantially to later South Asians. However, Steppe pastoralist ancestry appeared in outlier individuals at BMAC sites by the turn of the second millennium BCE around the same time as it appeared on the southern Steppe. Using data from ancient individuals from the Swat Valley of northernmost South Asia, we show that Steppe ancestry then integrated further south in the first half of the second millennium BCE, contributing up to $30 \%$ of the ancestry of modern groups in South Asia. [...] The primary ancestral population of modern South Asians is a mixture of people related to early Holocene populations of Iran and South Asia that we detect in outlier individuals from two sites in cultural contact with the Indus Valley Civilization (IVC), making it plausible that it was characteristic of the IVC. After the IVC's decline, this population mixed with northwestern groups with Steppe ancestry to form the "Ancestral North Indians" (ANI) and also mixed with southeastern groups to form the "Ancestral South Indians" (ASI), whose direct descendants today live in tribal groups in southern India. Mixtures of these two post-IVC groups - the ANI and ASI drive the main gradient of genetic variation in South Asia today. (Narasimhan et al. 2019a: 999)
}

It seems, then, that the earliest Aryan-speaking immigrants to South Asia, the Copper Hoard people, came with bull-drawn carts (Sanauli and Daimabad) via the BMAC and had Proto-IndoIranian as their language. They were, however, soon followed (and probably at least partially absorbed) by early Indo-Aryans, for the horse is depicted already in the BMAC-type bifacial seal from Prabhas Patan (Somnath) in Saurashtra, Gujarat (Joshi \& Parpola (eds) 1987 CISI 1: 359). 
Horse burials and horse sculptures are associated with the early (Ghalegay IV-V) phase of the Gandhāra Grave culture. These archaeological finds from Gandhāra seem to be connected with the gharma (alias pravargya) cult of the Aśvins (the divine counterparts of the chariot warrior and the charioteer); the gharma cult is first attested in the late books of the Rgveda, and therefore it was probably introduced into the Vedic tradition only after the Rgvedic IndoAryans had entered South Asia. This hypothesis is supported by Vedic statements according to which the Aśvins were not originally entitled to receive the soma drink in the soma cult of the Rgvedic tradition (Parpola 2015a: 117-129). The here-assumed pre-Rgvedic wave of Indo-Aryan speakers probably came from the Petrovka culture, which succeeded the Sintashta culture and spread with horse-drawn chariots from the Trans-Urals to Kazakhstan and southern Central Asia (Figure 24). I have argued that the Rgvedic wave, coming to South Asia several centuries later, perhaps in the fourteenth century $\mathrm{BCE}$, would have represented the originally eastern Andronovo variant, the Fëdorovo culture.

\section{THE ATHARVAVEDIC TRADITION}

In Stephanie Jamison's opinion, the linguistic and religious differences between the Rgveda and the Atharvaveda are not great enough to warrant a gap of some 500 years between the posited two major waves of Indo-Aryan immigration to South Asia. Here I can just point out that we do not have access to pre-Vedic texts of the Atharvavedic tradition, although it seems likely that they are content-wise ("magic" and royal rituals) reflected in the millennia-later texts of Śaiva-Śākta Tantrism, while their different linguistic features may have been inherited into the eastern Prakrits. In The Roots of Hinduism, I wrote:

\footnotetext{
The possible BMAC origin of the Gangetic copper hoards [...] suggests that Indo-Aryan speakers moved to the middle Ganges Valley so early that they did not become part of the Vedic culture. Such early Indo-Aryan speakers of the "Atharvavedic" wave of immigration seem to be meant when Vedic texts refer to "easterners" as asura worshippers and speakers of a language resembling eastern Middle Indo-Aryan, the Māgadhī Prakrit [...] In the Brāhmaṇa period, however, the Vedic culture expanded to the middle Ganges Valley, which led to an upsurge of ideas and practices in the Upanișads that were novel from the Vedic point of view but that had been developing for a longer time in eastern India, as is evident from the heterodox religions. (Parpola 2015a: 150)
}

A similar upsurge of new ideas and practices is evidenced in the late tenth book of the Rgveda, composed after the Rgvedic Indo-Aryans had settled in the Indus Valley. On the other hand, our Atharvavedic texts seem to result from a longer linguistic and ideological assimilation to the dominant Rgvedic tradition, which probably was a condition for the Atharvavedins to be accepted as members of the Vedic community and which is likely to have levelled away some linguistic and religious differences.

\section{RELIGION OF THE PETROVKA INDO-ARYANS}

Archaeological evidence suggests that the two principal variants of the Andronovo culture successively took over the power in the BMAC of southern Central Asia: the Petrovka during the "urban" period (which ended c.1750 BCE) and the Fëdorovo in the "post-urban" period (which ended c.1500). In The Roots of Hinduism, I have proposed that the invention of the horse-drawn chariot in the Sintashta culture created the cult of the 'horses-possessing' Aśvin twins as the divinized chariot team, who became the leading deities of the pantheon and 
reflected the new concept of dual kingship, where the king (the chariot warrior) shared the power with the high priest (the charioteer). During the "urban" period of the BMAC, the tin trade (Boroffka et al. 2002; Cierny, Stöllner \& Weisgerber 2005) brought the BMAC elite into contact with the Assyrian traders of Anatolia (Trolle Larsen 2015). Assyrian ideas of kingship seem to have prompted the Aryan rulers of the BMAC to create new divinities representing social virtues, the Ādityas, who parallel such "attributes" of the divine king in Assyrian religion. The two foremost of these new divinities, Mitra and Varuna, then took over the dual kingship from the Aśvins, who retained their association with the chariot (Parpola 2015a: 107-116).

\section{RELIGION OF THE FËDOROVO INDO-ARYANS}

The eastern Fëdorovo branch of the Andronovo community descended early on from the Petrovka culture, and differentiated in western Siberia due to local influences (Molodin 2001: 89-91). Plastic arts, especially sculptures depicting horses (Kovtun 2013; Parpola 2015a: 64-65, Figs. 7.8-9), show that the Fëdorovo people were strongly influenced ideologically by the Sejma-Turbino metallurgists of south Siberia (Kuz'mina 2007: 177-181). High-class weapons and tools of tin-bronze were produced in southern Siberia and transported through the SejmaTurbino trade network along the Irtysh and $\mathrm{Ob}$ rivers and along the border between the forest steppe and taiga to the west of the Urals (Turbino) and to the Mid-Volga (Sejma), to the area of the expanded Abashevo culture. The Abashevo culture was probably bilingual in ProtoIndo-Iranian and Proto-Uralic languages. Without being affected by the religious innovations that took place in the Sintashta and BMAC cultures, the Proto-Indo-Iranian pantheon of the Abashevo culture was in all likelihood headed by the counterpart of the Greek high god Zeus and Roman Jupiter, that is, the god of the sky, day, and thundery weather $\left({ }^{*}\right.$ Deiwo-s $>*^{*}$ Daiva-s [> Vedic Deva-s], whence Finnish taivas, 'sky'; Holopainen 2019: 270-271). The ProtoFinno-Ugrian name of the god of the sky and thundery weather (Ilmar-i of the Finnic folk epic Kalevala, Udmurt ilmer, inmar 'god') was *Ilma-ra (derived with the originally Aryan suffix -ra from Proto-Uralic *ilma, 'air, atmosphere, weather'). Transmitted to the Fëdorovo IndoAryans - either directly from Abashevo in Bashkiria or through the Sejma-Turbino network in southern Siberia - this seems to be the ultimate source of Indra, the name of the chief deity of the Rgvedic pantheon, god of the sky and thundery weather (Parpola 2015a: 66; 2019b). The principal cult drink of Indra worship, *sauma, was a juice pressed out of the soaked twigs of a plant whose botanical identity has been much debated and continues to be so (Clark 2017). A very serious - and probably the most likely - candidate is the ephedra plant (Nyberg 1995; Houben (ed.) 2003). One apparently neglected argument in favour of ephedra is the Old Persian name Sakā haumavarga for a branch of the Saka nomads; only the first part of the compound haumavarg $\bar{a}$ has a generally agreed interpretation, that it refers to Avestan haoma $=$ Vedic soma (Schmitt 2003). From a number of graves in Xinjiang (Ördek's Necropolis, graves in the delta of Qum-darya), archaeologists have found bunches of ephedra twigs in pockets of the funeral clothing (Bergman 1939: 70-73, 86-88, 99, 134, 138-139), and in one case the headgear of the dead suggests Saka identity (Bergman 1939: 137). There is much evidence for the presence of Fëdorovo people in Xinjiang (Kuz'mina 2007: 251-266), and it seems possible to suppose that they adopted the cultic use of ephedra there. 


\section{FORMATION OF THE VEDIC AND AVESTAN RELIGIONS}

Taking over the power in the BMAC around $1750 \mathrm{BCE}$, over the course of centuries the presumably Indra-worshipping Fëdorovo Indo-Aryans absorbed the Petrovka Indo-Aryans, who had been ruling the BMAC before them. In this process Mitra and Varuna became members of the Fëdorovo pantheon as well. Both branches should have inherited the Aśvin cult from the Sintashta culture. As a result, the BMAC-derived Mitanni Indo-Aryans (c.1500-1300 BCE) had Indra, the Aśvins, and Mitra and Varuna as their principal divinities, and they all are present also in the Rgveda, which was recorded after these Indo-Aryans coming from the "post-urban" phase of the BMAC eventually reached South Asia. When the Proto-Iranian speakers of the Roller Pottery cultures (Figure 26) came riding from the Pontic steppes to Central Asia around $1500 \mathrm{BCE}$, they took over the area where the BMAC had existed: the BMAC was now succeeded by the Yaz I culture (c.1500-1000 BCE). Over the course of centuries, the Proto-Iranian speakers absorbed the remaining Fëdorovo Indo-Aryans of southern Central Asia. This process led the Iranians to adopt the Fëdorovo *sauma cult, which explains the similarities between the Avesta and the Rgveda. On the other hand, the Yaz I period marks the beginning of the complete absence of archaeologically attested burials in southern Central Asia, which continued until Achaemenid times and implies the adoption of the exposure burial characteristic of Zoroastrianism.

\section{CONCLUSION}

In The Roots of Hinduism (2015a: 53-54) and in a later study (2017), I mistakenly correlated Proto-Iranian with the Catacomb Grave culture (c. 2500 or even 2800 to $2000 \mathrm{BCE}$ ) of the Pontic steppes. This led to a distorted chronology of my archaeological model for the prehistory of the Indo-Iranian languages, which was rightly criticized by Stephanie Jamison (2020). Replacing the Catacomb Grave culture as the archaeological correlate of Proto-Iranian with the Srubnaya culture (c.1850-1500 BCE) of the East European steppes makes more sense archaeologically and linguistically, and it shortens the chronology by about a millennium. The remaining parts of my model can be adjusted to match this replacement, and the resulting reconstruction actually works much better for the earliest Finno-Ugrian loanwords from Indo-Iranian. The dramatic new discovery of cart burials dated to c.1900 at Sanauli have been reviewed in this paper, and they support my proposal of a pre-Rgvedic wave (now set of waves) of Aryan speakers arriving in South Asia and their making contact with the Late Harappans.

\section{REFERENCES}

AgHA, Eran 2018. Dating Mahabharata to 2000 BC: Archaeologists Shift from Painted Grey Ware to Ochre Coloured Pottery. News18.com. 2 Sept. 2018.

Agrawal, Dharma Pal 1971. The Copper Bronze in India. Delhi: Munshiram Manoharlal Publishers.

Agrawal, Dharma Pal \& Jeewan Singh Kharakwal 2003. Bronze and Iron Ages in South Asia. New Delhi: Aryan Books International.

Agrawal, Dharma Pal, R.V. Krishnamurthy, Sheela Kusumgar, L.A. Narain \& M.N. Sarin 1974. Alloying in the Copper Hoards. Bulletin of the Museum and Archaeology 14: 14-18.

Agrawal, Dharma Pal, R.V. Krishnamurthy \& Sheela Kusumgar 1978. New Data on the Copper Hoards and the Daimabad Bronzes. Man and Environment 2: 41-46.

Ahluwalia, Disha 2018. Sanauli's Mysterious 'Warriors'. Live History India, 3 Dec. 2018. <https://www.livehistoryindia.com/cover-story/2018/12/03/sanaulis-mysterious-warriors>, accessed 20 Oct. 2020.

Амieт, Pierre 1977. La Bactriane proto-historique. Syria 54(1-2): 89-121. 
Anthony, David W. 2007. The Horse, the Wheel, and Language: How Bronze-Age Riders from the Eurasian Steppes Shaped the Modern World. Princeton: PUP.

Anthony, David W. \& Nikolai B. Vinogradov 1995. Birth of the Chariot. Archaeology 48(2): 36-41.

Benedetti, Giacomo 2020. The Sanauli Chariot and its Archaeological and Historical Context. In: N.I. Bukhtoyarov, I.M. Derkanosova, V.A. Gulevskiu, Yu.V. Nekrasov, A.S. Menzhulova \& A.V. Linkina (eds), Aktual'nye problemy agrarnoj nauki, proizvodstva i obrazovaniya: 255-259. Voronezh: FGBOU VO Voronezhskij GAU.

Bergman, Folke 1939. Archaeological Researches in Sinkiang, Especially the Lop-Nor Region. (Reports from the Scientific Expedition to the North-Western Provinces of China under the Leadership of Dr Sven Hedin The Sino-Swedish Expedition - Publication 7: Archaeology 1) Stockholm: Bokförlags Aktiebolaget Thule.

Bisht, R.S. 2015. Excavations at Dholavira (1989-1990 to 2004-2005). New Delhi: Archaeological Survey of India.

Bовомulloev, Saïdmurâd 1997. Ein bronzezeitliches Grab aus Zardča Chalifa bei Pendžikent (Zerafšan-Tal). Archäologische Mitteilungen aus Iran und Turan 29: 121-134.

Boroffka, Nikolaus, Jan Cierny, Joachim Lutz, Hermann Parzinger, Ernst Pernicka \& Gerd Weisgerber 2002. Bronze Age Tin from Central Asia: Preliminary Notes. In: K. Boyle, C. Renfrew \& M. Levine (eds), Ancient Interactions: East and West in Eurasia: 135-159. Cambridge: McDonald Institute of Archaeology, University of Cambridge.

Chernykn, Evgenij Nikolaevich 1992. Ancient Metallurgy in the USSR: The Early Metal Age. Tr. Sarah Wright. (New Studies in Archaeology) Cambridge: CUP.

Cierny, Jan, Thomas Stöllner \& Gerd Weisgerber 2005. Zinn in und aus Mittelasien. In: Bergbau, Metallurgie, Industriezentren und Werkstätten von Handelsgütern: 431-448. Bochum: Deutsches Bergbau-Museum.

Clark, Matthew 2017. The Tawny One: Soma, Haoma, and Ayahuasca. London: Muswell Hill Press.

DuA, Rohan 2020. India's Largest Known Burial Site is 3,800 Years Old, Confirms Carbon Dating. Times of India. 22 Feb. 2020.

Francfort, Henri-Paul 2005. La civilisation de l'Oxus et les Indo-Iraniens et Indo-Aryens. In: G. Fussman, J. Kellens, H.-P. Francfort \& X. Tremblay, Arya, Aryens et iraniens en Asie centrale (Collège de France, Publications de l'Institut de Civilisation Indienne 72): 253-328. Paris: Diffusion De Boccard.

Gening, Vladimir Fedorovich, Gennadij Borisovich Zdanovich \& Vladimir Vladimirovich Gening 1992. Sintashta: Arkheologicheskie pamyatniki arijskikh plemen Uralo-Kazakhstanskikh stepej, I. Chelyabinsk: YuzhnoUral'skoe knizhnoe izdatel'stvo.

Gubaev, Annageldy, Gennadij Andreevich Koshelenko \& Maurizio Tosi (eds) 1998. The Archaeological Map of the Mughab Delta: Preliminary Reports 1990-95. Text and Figures. (Istituto Italiano per l'Africa e l'Oriente, Centro Scavi e ricerche archaeologiche, Reports and Memoirs, Series Minor, III) Rome: IsIAO.

HAAK, Wolfgang et al. 2015. Massive Migration from the Steppe was a Source for Indo-European Languages in Europe. Nature 522: 207-211. https://doi.org/10.1038/nature14317.

Hauptmann, Andreas 1989. Chemical Analyses of Prehistoric Metal Artefacts from the Indian Subcontinent. In: P. Yule, The Copper Hoards of the Indian Subcontinent: Preliminaries for an Interpretation, with Appendix I and II by Andreas Hauptmann and Michael J. Hughes (Jahrbuch des Römisch-Germanischen Zentralmuseums 36): 261-267. Mainz: Römisch-Germanisches Zentralmuseum.

Hiebert, Fredrik Talmage 1994. Origins of the Bronze Age Oasis Civilization in Central Asia. With foreword by C.C. Lamberg-Karlovsky and preface by V. I. Sarianidi. (American School of Prehistoric Research, Bulletin 42) Cambridge, MA: Peabody Museum of Archaeology and Ethnology, Harvard University.

Hiebert, Fredrik T. 1995. South Asia from a Central Asian Perspective. In: G. Erdosy (ed.), Language, Material Culture and Ethnicity: The Indo-Aryans of Ancient South Asia (Indian Philology and South Asian Studies 1): 192-205. Berlin: Walter de Gruyter.

Holopainen, Sampsa 2019. Indo-Iranian Borrowings in Uralic: Critical Overview of Sound Substitutions and Distribution Criterion. PhD dissertation, University of Helsinki. Helsinki: Unigrafia.

Houben, Jan E.M. 2003. The Soma-Haoma Problem. Electronic Journal of Vedic Studies 9(1a).

JAmison, Stephanie W. 2020. Review of: Asko Parpola, The Roots of Hinduism, New York: OUP, 2015. Journal of the American Oriental Society 140(1): 241-244. 
JARrIGE, Jean-François 1991. The Cultural Complex of Mehrgarh (Period VIII) and Sibri: The 'Quetta hoard'. In: M. Jansen, M. Mulloy \& G. Urban (eds), Forgotten Cities on the Indus: Early Civilization in Pakistan from the 8th to the 2nd Millennium B.C.: 94-103. Mainz: Philipp von Zabern.

JARrige, Jean-François 1995. Introduction. In: C. JARrige, J.-F. JARrige, R.H. MeAdow \& G. Quivron (eds), Mehrgarh Field Reports 1974-1985: From Neolithic Times to the Indus Civilization. The Reports of Eleven Seasons of Excavations in Kachi District, Balochistan, by the French Archaeological Mission to Pakistan: 1-103. Karachi: The Department of Culture and Tourism, Government of Sindh, Pakistan.

JARrige, Jean-François \& M. Usman HASAN 1989. Funerary Complexes in Baluchistan at the End of the Third Millennium in the Light of Recent Discoveries at Mehrgarh and Quetta. In: K. Frifelt \& P. Sørensen (eds), South Asian Archaeology 1985 (Scandinavian Institute of Asian Studies, Occasional Papers 4): 150-166. London: Curzon Press.

JARRIGE, Jean-François \& Gonzague QuIVRon 2008. The Indus Valley and the Indo-Iranian Borderlands at the End of the 3rd and the Beginning of the 2nd Millennium BC. In: E.M. RAVEN (ed.), South Asian Archaeology 1999 (Gonda Indological Studies 15): 61-83. Groningen: Egbert Forsten.

Joshi, Jagat Pati \& Asko Parpola (eds) 1987. Corpus of Indus Seals and Inscriptions, I: Collections in India. (Annales Academiae Scientiarum Fennicae, B 239 \& Memoirs of the Archaeological Survey of India 86) Helsinki: Suomalainen Tiedeakatemia.

Kenoyer, Jonathan Mark 2004. Die Karren der Induskultur Pakistans und Indiens. In: M. FAnsa \& S. BurmeISTER (eds), Rad und Wagen: Der Ursprung einer Innovation: Wagen im Vorderen Orient und Europa (Archäologische Mitteilungen aus Nordwestdeutschland, Beiheft 40): 87-106. Mainz am Rhein: Verlag Philipp von Zabern.

Kovtun, Igor' Vyacheslavovich 2013. Predystoriya indoarijskoj mifologii. Kemerovo: Rossijskaya Akademiya Nauk, Sibirskoe otdelenie, Institut èkologii cheloveka.

Kumar, K. \& K. Rajan 2016. Archaeology of Vellore Region, Tamil Nadu. Man and Environment 41(2): 50-84.

Kumar, Vijay 2018. A Note on Chariot Burials Found at Sinauli District Baghpat U.P. Indian Journal of Archaeology 3(2): 735-755. <ijarch.org/Abstract.aspx?articleno=200>, accessed 20 Oct. 2020.

Kupriyanova, Elena, Andrey Epimakhov, Natalia Berseneva \& Andrey Bersenev 2017. Bronze Age Charioteers of the Eurasian Steppe: A Part-Time Occupation for Select Men? Praehistorische Zeitschrift 92(1): 40-65.

Kupriyanova, Elena V. \& Dmitrij Gennadievich Zdanovich 2015. Drevnosti lesostepnogo Zaural'ya: Mogil'nik Stepnoe VII. Chelyabinsk: Èntsiklopediya.

Kuz'mina, Elena Efimovna 2003. Origins of Pastoralism in the Eurasian steppes. In: M. Levine, C. Renfrew \& K. Boyle (eds), Prehistoric Steppe Adaptation and the Horse: 203-232. Cambridge: McDonald Institute for Archaeological Research, University of Cambridge.

KuZ'MinA, Elena Efimovna 2007. The Origin of the Indo-Iranians. Ed. J.P. Mallory. (Leiden Indo-European Etymological Dictionary Series 3) Leiden: Brill.

KuzNETsov, Pavel Fedorovich 2006. The Emergence of Bronze Age Chariots in Eastern Europe. Antiquity 80: 638-645.

Kuznetsov, Pavel Fedorovich (ed.) 2010. Koni, kolesnitsy i kolesnichie stepej Evrazii / Horses, chariots and chariot's drivers of Eurasian steppes. Ekaterinburg: Russian Academy of Sciences, Ural Branch, Institute of Plants and Animals Ecology.

Lal, Braj Basi, Jagat Pati Joshi, Arun Kumar Sharma, Madhu Bala \& K.S. Ramachandran 2015. Excavations at Kalibangan: The Harappans (1960-69), I. (Memoirs of the Archaeological Survey of India 110) New Delhi: Archaeological Survey of India.

LitTAuer, Mary Aiken \& Joost H. Crouwel 1977. Origin and Diffusion of the Cross-Bar Wheel? Antiquity 51: 95-105.

LitTAuer, Mary Aiken \& Joost H. Crouwel 1979. Wheeled Vehicles and Ridden Animals in the Ancient Near East. Drawings by J. Morel. (Handbuch der Orientalistik 7:1:2:B:1.) Leiden: Brill.

Mallory, James Patrick 1989. In Search of the Indo-Europeans: Language, Archaeology and Myth. London: Thames \& Hudson.

Mallory, James Patrick 1998. A European Perspective on Indo-Europeans in Asia. In: V.H. MAIr (ed.), The Bronze and Iron Age Peoples of Eastern Central Asia, I (The Journal of Indo-European Studies Monograph 26(1)): 175-201. Washington, D.C.: Institute for the Study of Man. 
Mallory, James Patrick 2002. Archaeological Models and Asian Indo-Europeans. In: N. Sims-WiLliams (ed.), IndoIranian Languages and Peoples (Proceedings of the British Academy 116): 19-42. Oxford: Published for The British Academy by Oxford University Press.

Manjul, Sanjay Kumar \& Arvin Manjul 2018. Recent Excavation at Sanauli, District Bagpat, UP: A Landmark in Indian Archaeology. Purātattva 48: 220-225 \& pl. 1-12.

Meadow, Richard H. (ed.) 1991. Harappa Excavations 1986-1990: A Multidisciplinary Approach to Third Millennium Urbanism. (Monographs in World Archaeology 3) Madison: Prehistory Press.

Molodin, Vyacheslav I. 2001. Westsibirien, der Altaj und Nordkazachstan in der entwickelten und späten Bronzezeit. In: R. Eichmann \& H. Parzinger (eds), Migration und Kulturtransfer: Der Wandel vorder- und zentralasiatischer Kulturen im Umbruch vom 2. zum 1. vorchristlichen Jahrtausend (Kolloquien zur Vor- und Frühgeschichte 6): 85-100. Bonn: Dr. Rudolf Habelt.

Narasimhan, Vagheesh M. et al. 2019a. The Formation of Human Populations in South and Central Asia. Science eaat7487 (6 Sept. 2019): 1-15. [Research article]

Narasimhan, Vagheesh M. et al. 2019b. The Formation of Human Populations in South and Central Asia. Science 365: 999 (6 Sept. 2019). [Research article summary]

Nautiyal, Vinod, Dharma Pal Agrawal \& R.V. Krishnamurthy 1981. Some Analyses on the Protohistoric Copper Artifacts. Man and Environment 5: 48-51.

Nyberg, Harri 1995. The Problem of the Aryans and the Soma: Botanical Evidence. In: G. Erdosy (ed.), The IndoAryans of Ancient South Asia: Language, Material Culture and Ethnicity (Indian Philology and South Asian Studies 1): 382-406. Berlin: Walter de Gruyter.

Otroshchenko, Vitaliy Viktorovych 2003. The Economic Peculiarities of the Srubnaya Cultural-Historical Entity. In: M. Levine, C. Renfrew \& K. Boyle (eds), Prehistoric Steppe Adaptation and the Horse: 319-328. Cambridge: McDonald Institute for Archaeological Research, University of Cambridge.

Parpola, Asko 1988. The Coming of the Aryans to Iran and India and the Cultural and Ethnic Identity of the Dāsas. Studia Orientalia 64: 195-302.

Parpola, Asko 2015a. The Roots of Hinduism: The Early Aryans and the Indus Civilization. NY: OUP.

Parpola, Asko 2015b. The Mohenjo-Daro Axe-Adze. Current World Archaeology 74: 14-15.

PARPola, Asko 2017. Finnish vatsa Sanskrit vatsá- and the Formation of Indo-Iranian and Uralic Languages. Journal de la Société Finno-Ougrienne 96: 245-286.

PARpola, Asko 2018. Vedic prākāśá- = prāvepá-: 'metal mirror', 'ear-drop', or 'whip'? In: M.F. AL'BEDIL' \& N.A. YanchevskaYa (eds), Mitrasampradānam: Sbornik nauchnykh statej $k$ 75-letiyu Yaroslova Vladimirovicha Vasil'kova: 65-92. Sankt-Peterburg: Muzej antropologii i ètnografii im. Petra Velikogo (Kunstkamera), Rossijskaya Akademiya Nauk.

PARpola, Asko 2019a. On Ancient Indian Ox-Carts, Biers, Beds and Thrones: À Propos of Sanskrit śakați- / śakațaand its Etymology. In: C. Wessels-Mevissen \& G.J.R. Mevissen (eds), Indology's Pulse: Arts in Context: Essays Presented to Doris Meth Srinivasan in Admiration of her Scholarly Research: 3-44. New Delhi: Aryan Books International.

Parpola, Asko 2019b. Jumal' avita! In: S. Junttila \& J. Kuokkala (eds), Petri Kallio Rocks: Liber semisaecularis 7.2.2019: 139-152. Helsinki: Kallion etymologiseura.

Piggott, Stuart 1992. Wagon, Chariot and Carriage: Symbol and Status in the History of Transport. London: Thames \& Hudson.

Pottier, Marie-Hélène 1984. Matériel funéraire de la Bactriane méridionale de l’Âge du Bronze. Dessins de Guy Samoun. (Recherche sur les Civilisations, Mémoire 36) Paris: Éditions Recherche sur les Civilisations.

Prabhakar, V. Nandagopal 2012. Burial Practices of the Harappans: Sanauli Excavation - A Case Study. Unpublished $\mathrm{PhD}$ thesis, Kurukshetra University.

Prabhakar, V. Nandagopal 2013a. Ceramic Typology of the Late Harappan Cemetery at Sanauli, Uttar Pradesh. Heritage: Journal of Multidisciplinary Studies in Archaeology 1: 78-103.

Prabhakar, V. Nandagopal 2013b. Analysis of Beads from the Sanauli Burials of Late Harappan Context. Prāgdhārā 23: 63-93.

Pustovalov, Sergij Zhanovich 1994. Economy and Social Organisation of Northern Pontic Steppe / Forest-Steppe Pastoral Populations: 2750-2000 BC (Catacomb Culture). Baltic-Pontic Studies 2: 86-134. 
Pustovalov, Sergij Zhanovic 2000. Kurgan "Tyagunova Mogila" i problemy kolesnogo transporta YamnoKatakombnoj èpokhi v Vostochnoj Evrope. Stratum Plus 2000(2): 196-222.

Pustovalov, Sergij Zhanovic 2008. Yamno-katakombnye transportnye sredstva i kriterii vydeleniya boevykh kolesnits èpokhi bronzy. In: A.I. VASILENKO (ed.), Proiskhozhdenie i rasprostranie kolesnichestva: 100-112. Lugansk: Globus.

ReIch, David 2018. Who We Are and How We Got Here: Ancient DNA and the New Science of the Human Past. NY: Pantheon Books.

SARIANIDI, Viktor Ivanovich 1986. Die Kunst des alten Afghanistan: Architektur, Keramik, Siegel, Kunstwerke aus Stein und Metall. Übersetzt aus dem Russischen von Sabine Grebe. Weinheim: VCH Verlagsgesellschaft.

SARIANIDI, Victor 2007. Necropolis of Gonur. English translation by Inna Sarianidi. Athens: Kapon Editions.

Schмid, Erich F. 1933. Tepe Hissar Excavations, 1931. The Museum Journal 23(4): 321-483.

Schmid, Erich F. 1937. Excavations at Tepe Hissar, Damghan. Philadelphia: University Museum.

Schmitt, Rüdiger 2003. Haumavargā. In: E. Yarshater (ed.), Encyclopaedia Iranica, XII, Fasc. 1: 63-64.

Shah, Sayid Ghulam Mustafa \& Asko Parpola (eds) 1991. Corpus of Indus Seals and Inscriptions, 2: Collections in Pakistan. (Annales Academiae Scientiarum Fennicae, B 240 \& Memoirs of the Department of Archaeology \& Museums, Government of Pakistan 5) Helsinki: Suomalainen Tiedeakatemia.

Sharma, Deo Prakash 2002. Newly Discovered Copper Hoard Weapons of South Asia (c. 2800-1500 B.C.). Delhi: Bharatiya Kala Prakashan.

Sharma, D.V., K.C. Nauriyal, V.N. Prabhakar \& Vishnukant 2005. Sanauli: A Late Harappan Burial Site in the Yamuna-Hindon Doab. Purātattva 34 (2003-2004): 35-44.

Sharma, D.V., K.C. Nauriyal \& V.N. PrabhaKar 2007. Excavations at Sanauli 2005-06: A Harappan Necropolis in the Upper Ganga-Yamuna Doab. Purātattva 36 (2006): 166-179.

Sherratt, Andrew 2003. The Horse and the Wheel: The Dialectics of Change in the Circum-Pontic Region and Adjacent Areas, 4500-1500 Bc. In: M. Levine, C. Renfrew \& K. Boyle (eds), Prehistoric Steppe Adaptation and the Horse: 233-252. Cambridge: McDonald Institute for Archaeological Research, University of Cambridge.

Shinde, Vasant 2011. Harappan Cemetery at Farmana. In: V. Shinde, T. Osada \& M. Kumar (eds), Excavations at Farmana, District Rohtak, Haryana, India, 2006-2008: 530-673. Kyoto: Indus Project, Research Institute for Humanity and Nature.

SingH, Upinder 2008. A History of Ancient and Early Medieval India: From the Stone Age to the 12th Century. Delhi: Pearson Longman.

Sparreboom, Marcus 1985. Chariots in the Veda. (Memoirs of the Kern Institute 3) Leiden: Brill.

Stol, Marten \& Ursula Seidl 2015. Waffen im alten Mesopotamien. Bibliotheca Orientalis 72(5-6): 613-626.

Subramanian, Thinniam Sivam 2018. Royal Burial in Sanauli. Frontline. 28 Sept. 2018. $<$ https://frontline.thehindu.com /arts-and-culture/heritage/article24923229.ece>, accessed 20 Oct. 2020.

Trolle Larsen, Mogens 2015. Ancient Kanesh: A Merchant Colony in Ancient Anatolia. Cambridge: CUP.

WheELer, Robert Eric Mortimer 1947. Harappā 1946: The Defences and Cemetery R 37. Ancient India 3: 58-130.

WheELER, Mortimer 1968. The Indus Civilization. (Supplementary volume to The Cambridge History of India) 3rd edn. Cambridge: CUP.

YAAJNASEnI 2018. Carbon Dating Shows UP's Sanauli Had Chariot-Riding Warriors in 1900 BC. Swarajya 24 Feb. 2018. Yule, Paul 1985. Metalwork of the Bronze Age in India. (Prähistorische Bronzefunde XX(8)) München: Verlag C.H. Beck. Yule, Paul 1989 [1992]. The Copper Hoards of the Indian Subcontinent: Preliminaries for an Interpretation, with Appendix I and II by Andreas Hauptmann and Michael J. Hughes. Jahrbuch des Römisch-Germanischen Zentralmuseums 36: 193-275. Mainz: Römisch-Germanisches Zentralmuseum.

Zdanovich, Dmitrij Gennadievich (ed.) 2002. Arkaim: Nekropol' (po materialam kurgana 25 Bol'shekaraganskogo mogil'nika), I. Chelyabinsk: Yuzhno-Ural'skoe knizhnoe izdatel'stvo. 